\title{
Modeling of climate forcing on a cold-ocean ecosystem, Conception Bay, Newfoundland
}

\author{
Ru Cheng Tian ${ }^{1,2, *}$, Don Deibel ${ }^{1}$, Raymond J. Thompson ${ }^{1}$, Richard B. Rivkin ${ }^{1}$ \\ ${ }^{1}$ Ocean Science Center, Memorial University, St. John's, Newfoundland A1C 5S7, Canada \\ ${ }^{2}$ Present address: Harvard University, Department of Earth and Planetary Sciences, 29 Oxford Street, Cambridge, \\ Massachusetts 02138, USA
}

\begin{abstract}
Climate forcing of marine ecosystems has been the subject of increased research over the last few decades. We have developed a prognostic, 1-dimensional (1D) physical-biological model to study climate forcing of cold-ocean ecosystems. The physical model is based on the MellorYamada level 2.5 turbulence closure scheme and is explicitly driven by meteorological data. The biological model consists of 10 state variables which include the mesoplankton and the microbial food webs. The model was applied to Conception Bay, Newfoundland, Canada with meteorological, physical and biological data collected from 1986 to 1990. Our model revealed a strong correlation between the NAO (North Atlantic Oscillation) index and biological production. The microbial food web (e.g. small phytoplankton, microzooplankton and bacteria) is more sensitive to climate variability than is the mesoplankton food web (e.g. large phytoplankton and mesozooplankton). Buoyancy flux-driven convective mixing, temperature and solar radiation are the major factors through which climate variability affects the function of cold-ocean ecosystems.
\end{abstract}

KEY WORDS: Climate forcing $\cdot$ Vertical mixing $\cdot$ Phytoplankton bloom $\cdot$ Simulation model

\section{INTRODUCTION}

Climate is changing, due to both natural processes (e.g. El Niño Southern Oscillation and North Atlantic Oscillation) and anthropogenic greenhouse gas emissions such as $\mathrm{CO}_{2}$ (Barnett et al. 2001, ICPP 2001). Climate variability and extreme weather events have the potential to perturb ecosystem function. Changes in the structure, function and productivity of marine ecosystems in response to large-scale, low-frequency climatic variations have been a subject of increased research over the last few decades (Polovina et al. 1994, Karl et al. 2001, Edwards et al. 2002). From the late 1960s to the late 1970s, climate-regime shifts took place in both the North Pacific and in the North Atlantic. The North Pacific Decadal Oscillation shifted from a positive to a negative phase in the winter of 1976/1977, then stagnated in its negative phase during the 1980s (Francis et al. 1998). The North Atlantic Oscillation stagnated in a negative phase from the late 1960s to the 1980s and turned to a positive phase in the early 1990s (Hurell 1995). From 1960 to 1980, warm weather prevailed in the NW Atlantic. Conditions were reversed during the early 1990s, with cold conditions in the NW Atlantic. These climate variations generated a series of shifts in ecosystem function in vast regions of the North Pacific and North Atlantic (Polovina et al. 1994, Planque \& Fromentin 1996). Changes in zooplankton community composition and production have been reported in the North Pacific (Sugimoto \& Tadokoro 1998) and in the North Atlantic (Planque \& Fromentin 1996). Dramatic changes in marine ecosystems may be underway, involving bacteria, corals, invertebrates, seagrasses, fishes, marine mammals and toxic dinoflagellates (Hayes et al. 2001). Understanding the relationship between climate change and marine ecosystem dynamics is thus critical for ecological preservation and sustainable exploitation of living resources.

Ecosystem models based on meteorological forcing and interactions between physical and biological 
dynamics can provide an insight into the mechanisms that connect climate variability and marine ecosystem function. In this paper we present a prognostic, coupled, physical-biological model to analyze climate forcing on a cold-ocean ecosystem, Conception Bay, Newfoundland. The physical model, based on the Mellor-Yamada turbulence closure scheme (Mellor \& Yamada 1982), is explicitly driven by meteorological data which generates vertical mixing coefficients (including turbulence diffusivity and static convective mixing), seawater temperature and irradiance. These 3 major output variables of the physical model were used to drive the biological model. The biological model consists of 10 state variables that include the microbial and the mesoplankton food webs through trophic interactions and energy flow among biotic and abiotic pools (Tian et al. 2000, 2001).

The model was applied to Conception Bay on the east coast of Newfoundland (Fig. 1). Due to strong seasonal variations in heat flux, stratification, hydrodynamics and biological production, cold-ocean systems are particularly sensitive to climate variability (Shindell et al. 1999). Conception Bay is under the influence of the North Atlantic Oscillation (NAO), as is the entire North Atlantic. The NAO is a weather system that has strong interannual and interdecadal variations (Hurell 1995). Conception Bay is ca. $50 \mathrm{~km}$ upstream from St. John's Harbor and its shoreline is sparsely populated, with essentially no agriculture. Previous work has indicated very low levels of terres-

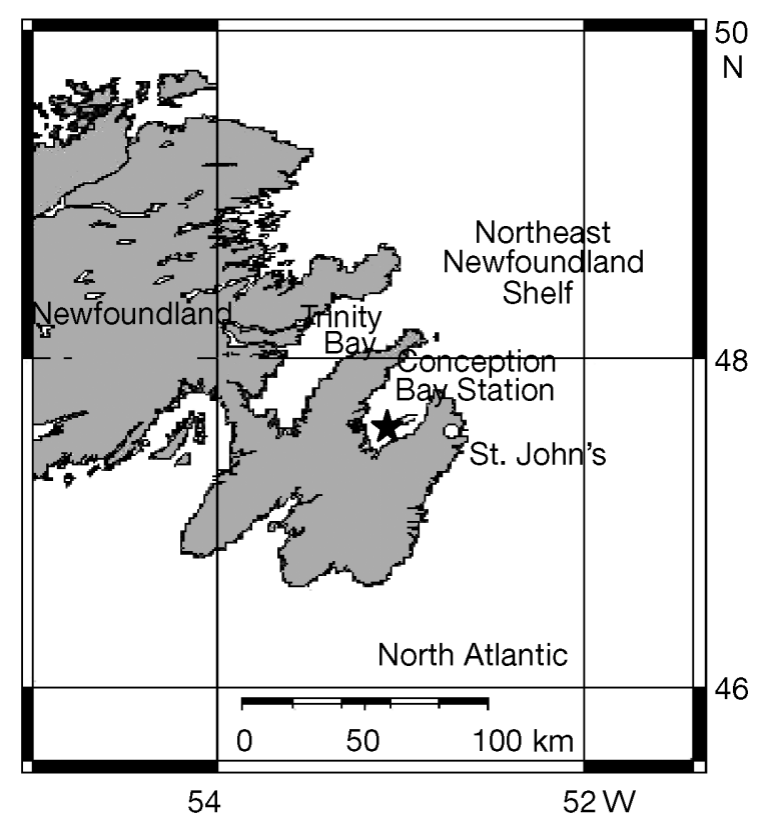

Fig. 1. East coast of Newfoundland, showing location of sampling station $(\star)$ in Conception Bay trial runoff and anthropogenic perturbation (Ostrom et al. 1997, Budge \& Parrish 1998). All these factors make Conception Bay a suitable site for studying climate forcing in cold-ocean ecosystems. An oceanographic research program, the Cold Ocean Productivity Experiment (COPE), was conducted from 1986 to 1990 in this region. This research program focused on interannual variability in the timing and production of the spring phytoplankton bloom and the subsequent energy flow from the pelagic to the benthic ecosystem. Meteorological, physical and biological data collected over these 5 years were used to constrain our model over the same period.

\section{MATERIALS AND METHODS}

We developed a prognostic, 1-dimensional (1D) physical model to calculate photosynthetically active radiation $(\mathrm{PAR})$, seawater temperature and the vertical mixing coefficient to drive a previously published biological model (Tian et al. 2000). Conception Bay opens up on the NE Newfoundland Shelf, where the inshore branch of the Labrador coastal current flows southward (DeYoung \& Sanderson 1995). Local air-sea heat flux accounts for $89 \%$ of the variation in water temperature (Umoh et al. 1995) and 1D models can approximate temperature profiles on the NE Newfoundland Shelf (Petrie et al. 1991). The focal Conception Bay time-series station is located in the inner bay, so that the influence of the Labrador Current on the heat budget should be lower than on the shelf. Due to low local freshwater discharge, however, water-mass exchange with the NE Newfoundland Shelf represents a major factor controlling salinity variations in Conception Bay (DeYoung \& Sanderson 1995). Mathieu \& DeYoung (1995) used data assimilation to simulate salinity profiles, whereas we used a prescribed salinity flux to represent the influence of bay-shelf water exchange on salinity in Conception Bay (Appendix 1).

Various models have been developed to simulate the hydrodynamics of the water column, including bulk mixed-layer models, eddy-coefficient models, turbulence-closure models and deterministic models (Niiler \& Kraus 1977, Martin 1985, Mathieu \& DeYoung 1995). We used the Mellor-Yamada level 2.5 turbulenceclosure scheme, which has been adapted for 1D biological simulation (Sharples \& Tett 1994, Kuhn \& Radaach 1997). Equations of the physical model are presented in Appendix 1. Since our objective was to capture climate impact on a marine ecosystem, meteorological forcings including air temperature, wind, cloudiness, precipitation and sea surface pressure were explicitly implemented. 
Vertical mixing includes wind-driven turbulence diffusivity and buoyancy flux-driven convective mixing in cold-ocean systems. We used the following geostrophic adjustment scheme to capture convective mixing (Marotzke 1991). At each time step, the model looks for static instability upward from the bottom of the water column (i.e. inverse density gradient) based on the criterion $\mathrm{d} \sigma_{t} / \mathrm{d} z>0.0001\left(\mathrm{~kg} \mathrm{~m}^{-2}\right)$, where $\sigma_{t}$ is the potential density of seawater and $z$ is the depth. This criterion was determined from the seawater kinematic viscosity, $0.01 \mathrm{~cm}^{2} \mathrm{~s}^{-1}$, which corresponds to a dynamic viscosity of 0.0001 kilogram-force $\mathrm{s} \mathrm{m}^{-2}$ (Myrhaug \& Slaattelid 1998). Once instability was detected, an explicit mixing coefficient $\left(0.25 \Delta z^{2} / \Delta t \mathrm{~m}^{2} \mathrm{~s}^{-1}\right.$, where $\Delta z$ and $\Delta t$ are the vertical resolution and time step of the model, respectively) was applied for all layers above the unstable zone. This procedure was repeated until all instability had been removed from the entire water column. The same convective mixing coefficient was then applied to biological state variables over the same depth range.

The biological model has been described previously (Tian et al. 2000, 2001). The basic structure of the model consists of a mesoplankton food web, including large phytoplankton $(>5 \mu \mathrm{m})$, mesozooplankton (>200 $\mu \mathrm{m})$, and large sinking particles, and the microbial food web, consisting of bacteria, small phytoplankton $(<5 \mu \mathrm{m})$, microzooplankton $(<200 \mu \mathrm{m})$, smallsuspended particles, and dissolved organic matter (DOM; Tian et al. 2000). Briefly, growth rates of both large and small phytoplankton are forced by photosynthetically active radiation (PAR), nitrogenous nutrients and temperature. PAR forcing is formulated as:

$$
\mu(\mathrm{PAR})=P_{\mathrm{m}}\left(1-\mathrm{e}^{-\alpha \mathrm{PAR} / P_{\mathrm{m}}}\right) \mathrm{e}^{-\beta \mathrm{PAR} / P_{\mathrm{m}}}
$$

where $\mu(\mathrm{PAR})=$ light-dependent growth rate $\left(\mathrm{d}^{-1}\right), P_{\mathrm{m}}=$ theoretical maximum biomass-normalized growth rate $\left(\mathrm{d}^{-1}\right), \alpha=$ initial slope of photosynthesis-irradiance relationship $\left(\mathrm{W}^{-1} \mathrm{~d}^{-1}\right)$ and $\beta=$ photoinhibition coefficient $\left(\mathrm{W}^{-1} \mathrm{~d}^{-1}\right.$; Platt et al. 1980). Both photosynthetic parameters are based on a carbon-to-chlorophyll ratio of 50. Limitation of phytoplankton growth by nitrogenous nutrients is parameterized as:

$$
\mu_{\mathrm{Pl}}(\mathrm{N})=\frac{\mathrm{NH}_{4}^{+}}{\mathrm{NH}_{4}^{+}+H_{\mathrm{PIA}}}+\frac{\mathrm{NO}_{3}^{-}}{\mathrm{NO}_{3}^{-}+H_{\mathrm{PIN}}} \times \frac{H_{\mathrm{PIA}}}{\mathrm{NH}_{4}^{+}+H_{\mathrm{PIA}}}(2)
$$

where $\mu_{\mathrm{Pl}}(\mathrm{N})$ [or $\mu_{\mathrm{Ps}}(\mathrm{N})$ ] = nutrient-limited growth rate of large (or small) phytoplankton, $H_{\mathrm{PIN}}$ and $H_{\mathrm{PlA}}=$ halfsaturation constants for $\mathrm{NO}_{3}{ }^{-}$and $\mathrm{NH}_{4}{ }^{+}$uptake $(\mu \mathrm{M})$ by large phytoplankton (or $H_{\mathrm{PsN}}$ and $H_{\mathrm{PsA}}$ for small phytoplankton), respectively (Parker 1993). Finally, temperature forcing is given by

$$
\mu_{\mathrm{Pl}}(\mathrm{T})=\mathrm{e}^{\beta_{\mathrm{TP}} \mathrm{T}}
$$

where $T=$ temperature in the surface mixed layer, $\mu_{\mathrm{P} 10}$ $\left(\right.$ or $\left.\mu_{\mathrm{Ps} 0}\right)=$ maximum growth rate at $0^{\circ} \mathrm{C}\left(\mathrm{d}^{-1}\right)$ for large (or small) phytoplankton, and $\beta_{\mathrm{TP}}=$ exponent of the temperature-dependence of phytoplankton growth rate (Verity 1981). The phytoplankton growth rate is computed as the product of these 3 terms:

$\mu_{\mathrm{Pl}}=\mu(\mathrm{PAR}) \mu_{\mathrm{Pl}}(\mathrm{N}) \mu_{\mathrm{Pl}}(\mathrm{T}) \quad\left(\right.$ or $\left.=\mu(\mathrm{PAR}) \mu_{\mathrm{Ps}}(\mathrm{N}) \mu_{\mathrm{Ps}}(\mathrm{T})\right)$

PAR calculation was carried out as detailed in Tian et al. (2000), and surface water temperature was computed by the physical model. Mesozooplankton are assumed in the model to feed on large phytoplankton, microzooplankton, and large particles, whereas microzooplankton consume small phytoplankton, bacteria, and small particles. The specific feeding rate of a predator $j$ on food type $i$ is calculated as:

$$
G_{j}^{i}=\frac{g_{j} C_{i} F_{i}}{1+F_{\mathrm{t}}}, \text { with } F_{\mathrm{t}}=\sum c_{i} F_{i}
$$

where $g_{j}=$ maximum grazing rate, $C_{i}=$ food preference (inverse of the half-saturation constant) and $F_{\mathrm{t}}=$ total food concentration (Tian et al. 2001). Temperature influence upon zooplankton grazing and bacterial uptake rates is parameterized by an exponential law as for phytoplankton (Eq. 3; see also Huntley \& Lopez 1992). Large sinking particles are composed of a mixture of faecal pellets, organic aggregates, and detritus of large, dead organisms. Small particles are formed through feeding losses (including sloppy feeding and defecation) and detritus of small dead organisms.

Data. Meteorological and physical data: Data for hourly wind velocity and direction, air temperature, barometric pressure, humidity, cloudiness and daily precipitation data were collected at St. John's Airport, $25 \mathrm{~km}$ from the sampling station at $47^{\circ} 32.2^{\prime} \mathrm{N}$, $53^{\circ}$ 07.9' $\mathrm{W}$ in Conception Bay. The weather conditions during the 5 yr period 1986 to 1990 were broadly comparable, illustrated by the similar seasonal pattern in the forcing data (Fig. 2). Nevertheless, air temperature was relatively lower in the winter and higher in the summer of 1989 and 1990 than in 1986 and 1987 (Fig. 2A,B). The NAO index was higher in 1989 (5.08) and 1990 (3.96) than in 1986 (0.5) and 1987 (-0.75). A high NAO index indicates strong westerly winds in winter and cold weather over the NW Atlantic and Conception Bay, so that the low temperature observed in eastern Newfoundland in the winters of 1989 and 1990 is consistent with the prediction from the NAO index. However, the high temperature in summer in these 2 cold-winter years was rarely noted in previous studies. Wind, cloudiness and precipitation are characterized by high-frequency variability (Fig. 2C-H). Late winter and early spring of 1987 were distinguished by weaker winds and greater cloudiness and precipitation than the other years.

During the COPE research program, 97 CTD profiles were collected at the study site between late March 
and early June during 1988, 1989 and 1990 using a SeaBird, SBE 25 CTD device. Another 67 CTD profiles were collected around the year at the same station from 1992 to 2000, allowing us to constrain the model over an annual cycle.

Biological data: In this section we briefly present the biological data used to constrain the model. A detailed description of the methodology is beyond the scope of this paper, and has been presented in other publications (i.e. Pomeroy et al. 1991, Redden 1994, Choe \& Deibel 2000). Phytoplankton biomass was estimated from chlorophyll a data using a constant carbon: chlorophyll a ratio of 50. Chlorophyll a concentration was measured by fluorometry (Yentsch \& Menzel 1963)
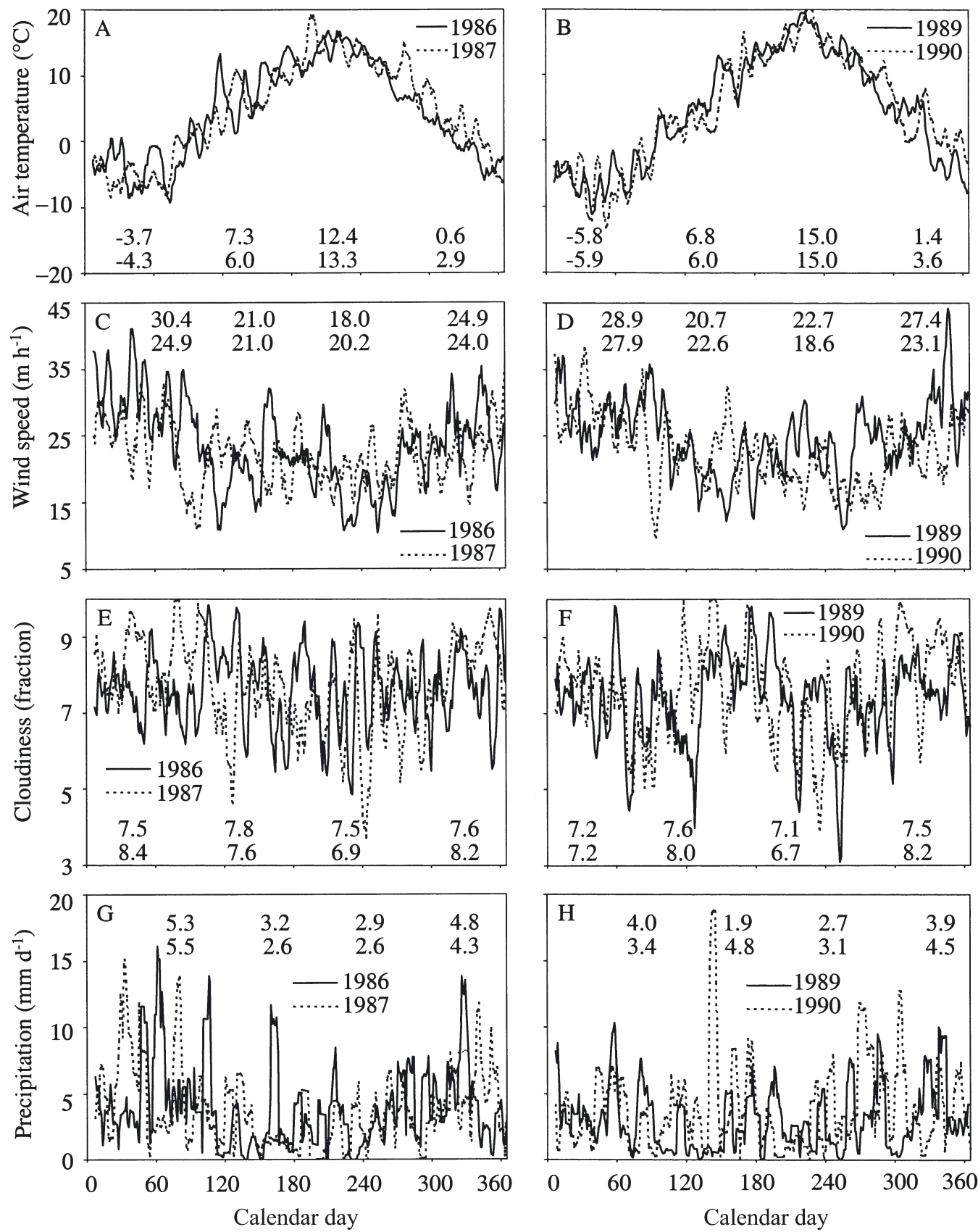

Fig. 2. Meteorological data used to drive the physical model from 1986 to 1990. Lines are the 5 d moving averages of forcing data and values are seasonal averages of corresponding variable in the following order: winter, January to March; spring, April to June; summer, July to September; autumn, October to December. Forcing data of 1988 and of humidity and pressure are not shown for simplicity of presentation 
Table 1. Number of data profiles used in this study. -: no data

\begin{tabular}{|lcccccc|}
\hline & 1986 & 1987 & 1988 & 1989 & 1990 & $1992-2000$ \\
\hline CTD & - & - & 40 & 30 & 27 & 67 \\
Chlorophyll a & 30 & - & 29 & 24 & 12 & - \\
Mesozooplankton & - & - & 16 & - & - & 16 \\
Microzooplankton & 25 & - & - & - & - & - \\
Bacteria & - & - & - & - & - & 34 \\
Nitrate & 30 & - & 26 & 24 & 14 & - \\
Sediment traps & - & - & 12 & - & - & - \\
\hline
\end{tabular}

at different depths from the surface to $100 \mathrm{~m}$, yielding 95 vertical profiles from 1986 to 1990 (Table 1). Most of these data were collected during the spring season in order to study the phytoplankton bloom.

Biomass of mesozooplankton, microzooplankton and bacteria was estimated from microscope counts, which were species- and stage-specific for the zooplankton, followed by conversion to carbon biomass units using literature values for the region. The mesozooplankton community in Conception Bay is dominated by Calanus finmarchicus, Pseudocalanus spp., Microcalanus spp., Oikopleura vanhoeffeni, O. labradoriensis, Metridia longa, Temora longicornis and Oithona spp. For copepods, conversion from the number of individuals to carbon biomass was based on factors given in Coyle et al. (1990), Conover \& Huntley (1991) and Durbin et al. (1995). Conversion factors for oikopleurid appendicularians came from Deibel (1986). The microzooplankton community was dominated by ciliates and microflagellates. Biovolumes were calculated based on diameter or length and width and then converted to biomass by using a factor of $0.14 \mathrm{pg} \mathrm{C}$ $\mu^{-3}$ (Quevedo \& Anadon 2000). For bacteria, the conversion factor was $20 \mathrm{fg}$ cell $^{-1}$. Samples of mesozooplankton were collected in 1988 and from 1997 to 1998. Samples of microzooplankton were collected in 1986, while bacteria were collected from 1992 to 1994 (Table 1). Moored sediment traps were deployed in 1988, as described in Redden (1994). Although there are temporal discrepancies between the data from various sources and the simulated period, these data outline the general seasonal cycles of various biological pools. Most of these field data have not been published, and detailed information can be acquired from the authors.

\section{RESULTS}

\section{Comparison between simulation and observations}

In this section we compare model output and observed results to validate the simulations. The magni- tude and vertical profiles of water temperature and salinity were comparable between simulations and observations (Fig. 3). Small discrepancies in absolute values between simulations and observations were generated on certain temperature (Fig. 3C-E) and salinity (Fig. 3G,I,J) profiles. The CTD data were collected from the late 1980s to the year 2000, whereas the model was forced by meteorological data from 1986 to 1990 . The model is 1-dimensional, and variation in 3D fields (e.g. the strength and properties of the Labrador Current) is not simulated. Salinity variation due to horizontal advection depends on ice cover at high latitudes and the coastal current pattern, whereas an averaged salinity flux was applied to the different simulated years (Appendix 1). Interannual variability in the vertical hydrodynamics due to changes in salinity flux can thus be overlooked. These discrepancies on various temporal and spatial scales between the model and data in part account for the mismatches between simulations and observations. Given the uncertainties in both the model and data, the general pattern in the vertical distribution and seasonal cycle of temperature and salinity were successfully reproduced by the model over the 5 yr period.

The water column is almost homogeneous in winter. Stratification begins in early April and reaches its maximum in August and September. Convective mixing begins in October due to heat loss (through sensible and latent heat fluxes) at the sea surface, which leads to the erosion of the thermocline and strong vertical mixing in winter. Heat-transfer across the weak thermocline in late fall may also contribute to the homogenization of the water column and vertical mixing (Pingree \& Pennycuick 1975). Both simulations and observations showed a slight temperature anomaly at about $60 \mathrm{~m}$ depth (Fig. 3A) due to a halocline in early winter.

The simulated seasonal cycles of phytoplankton biomass in the euphotic zone are comparable with the observations (Fig. 4). The magnitude of the spring phytoplankton bloom was successfully reproduced over the 5 yr modeled. The simulated peak of phytoplankton biomass in 1988 is slightly earlier than the observed maximum, so that our 1D model may underestimate interannual variability in the timing of the spring phytoplankton bloom. The phytoplankton bloom also terminates more rapidly than the model prediction. The model is nitrogen-driven. Limitation by other nutrient elements was not parameterized. The spring phytoplankton bloom generally consists of large diatoms which require silicate for growth. If silicate is first depleted in surface waters, the phytoplankton bloom will decline earlier than the model prediction. Grazing pressure from zooplankton represents another factor controlling the magnitude and the duration of 


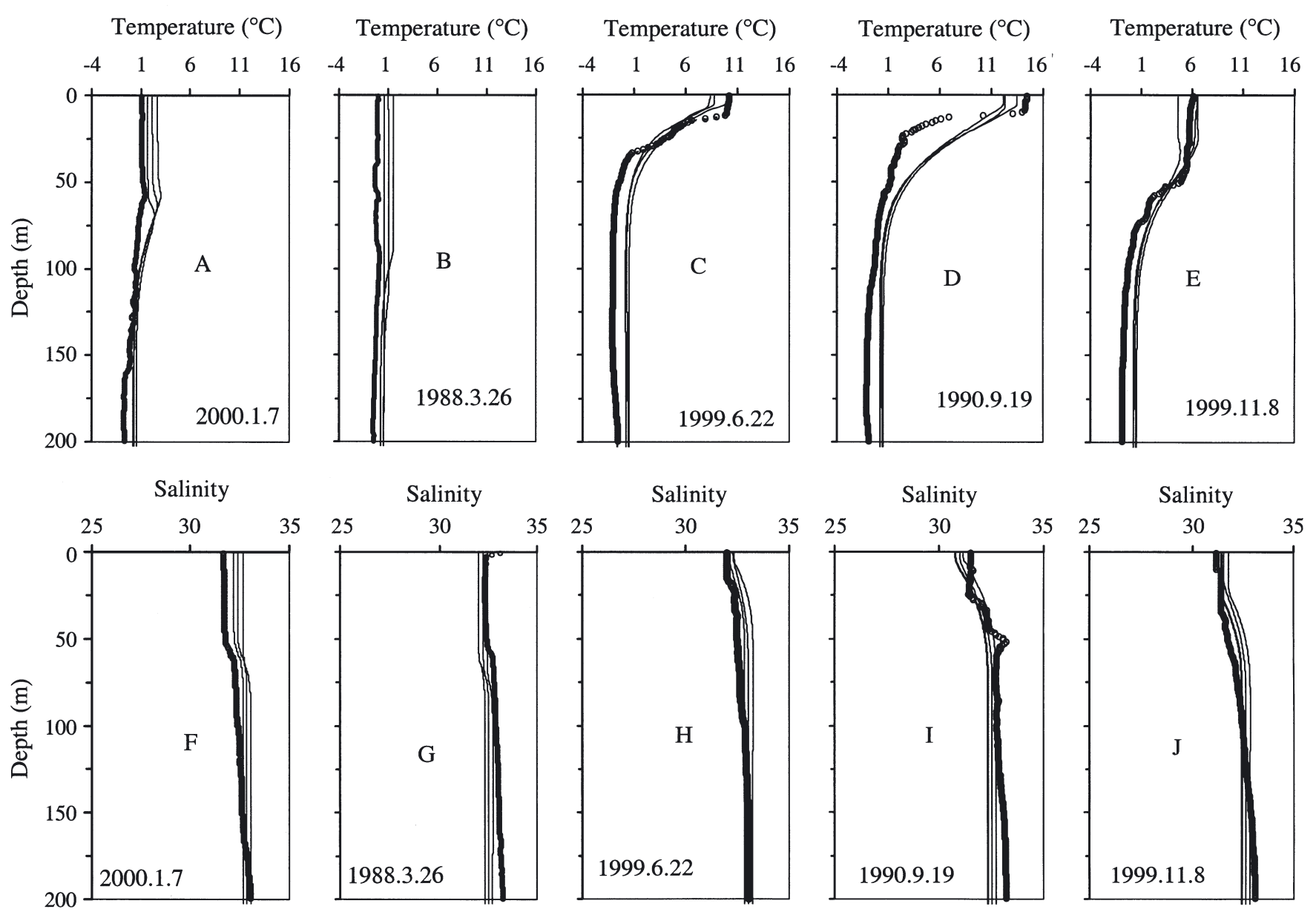

Fig. 3. Simulated (lines) and measured (circles) temperature and salinity profiles. These example profiles were selected to illustrate annual cycle of temperature and salinity in the water column. Collected data are for 1988 to 2000, whereas simulations are for 1986, 1988 and 1990. Dates are in order year/month/day

the spring phytoplankton bloom (Tian et al. 2000). As shown below, the model seems to underestimate grazing pressure during spring, which can explain in part the discrepancy between observation and simulation in the duration of the phytoplankton bloom.

Both the magnitude and seasonal cycle of bacterial biomass were reproduced by the model (Fig. 5A). The simulated magnitudes of microzooplankton and mesozooplankton biomass and particle-sinking flux are within the range of observed results, although the data show relatively large dispersion. The model seems to underestimate mesozooplankton biomass in spring (Fig. 5C). This discrepancy may result from zooplankton vertical migration that is not parameterized in the model. Recent studies have shown that zooplankton that diapause in deep water in winter may migrate to surface layers before or at the onset of the phytoplankton bloom and thus increase the grazing pressure (Head et al. 2000). On annual cycles, the model has been tested using time-series data of both meso- zooplankton and microzooplankton from a similar high-latitude environment on the west coast of Newfoundland (Tian et al. 2001).

\section{Vertical mixing}

Vertical mixing consists of wind-driven turbulence diffusivity and buoyancy flux-driven convective mixing. The simulated annual cycles of the turbulence diffusivity and convection coefficients for 1987 and 1989 are presented in Fig. 6 as examples. These 2 years represent respectively the weakest and strongest vertical mixing years over the simulated period. The vertical turbulence diffusivity is mainly driven by wind stress, whereas convection is generated by heat fluxes. In winter, deep vertical mixing is dominated by convection, whereas turbulence diffusion is limited to the upper $120 \mathrm{~m}$. Both vertical convection and wind-driven turbulence diffusivity have large seasonal variations, 

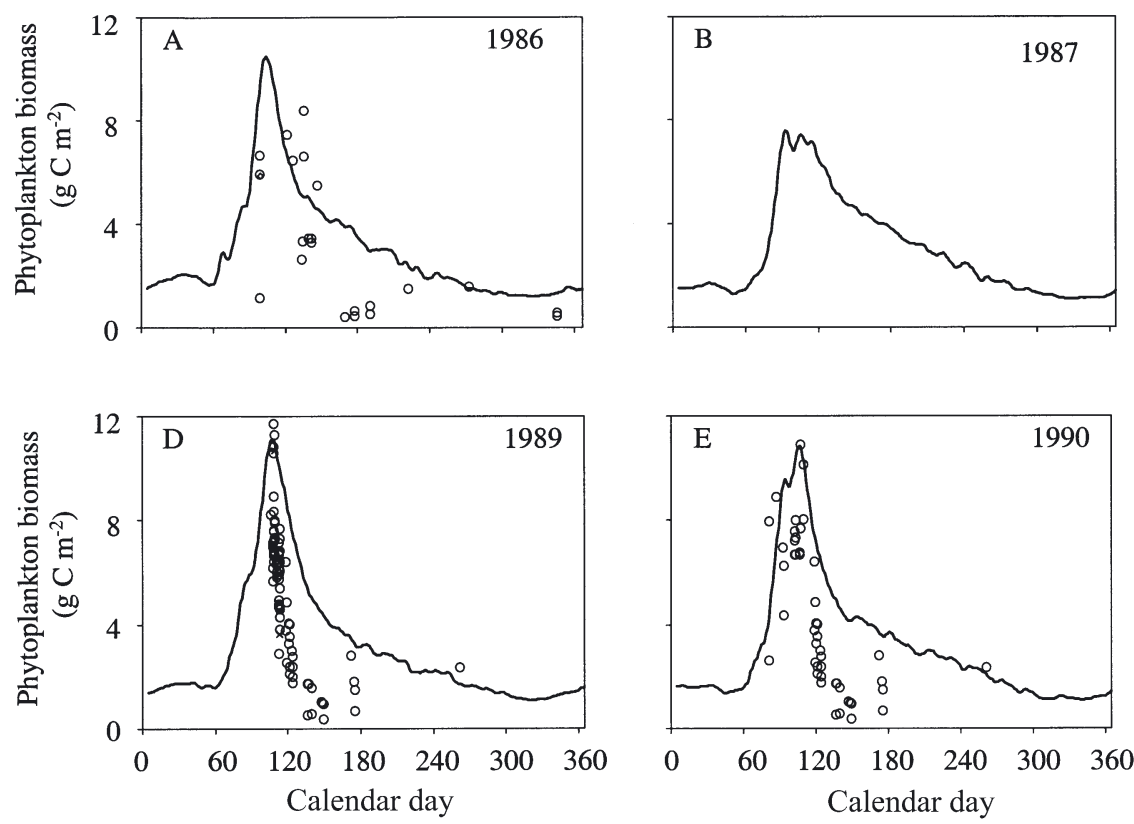

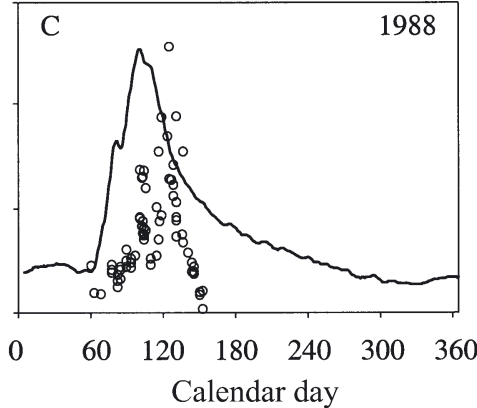

Fig. 4. Simulated (lines) and observed (circles) phytoplankton biomass integrated over euphotic zone. No measurements were conducted in 1987 with low values in summer when convection is essentially zero, with increasing values in autumn and maxima in winter. The increase in turbulent diffusivity in late autumn and winter is partly driven by the increase in vertical convection. The enhanced convection due to heat loss in late autumn and winter erodes the thermocline and deepens the surface mixed layer so that kinetic energy from wind stress can penetrate further into the water column.
The general patterns in seasonal cycle of both the vertical turbulence diffusivity and convection are similar between 1987 and 1989. However, the output of simulations revealed many strong, episodic vertical mixing events during early spring in 1989, whereas relatively weak vertical mixing was simulated in the same period in 1987. These strong vertical mixing events essentially resulted from enhanced vertical convection driven by heat loss at the sea surface.
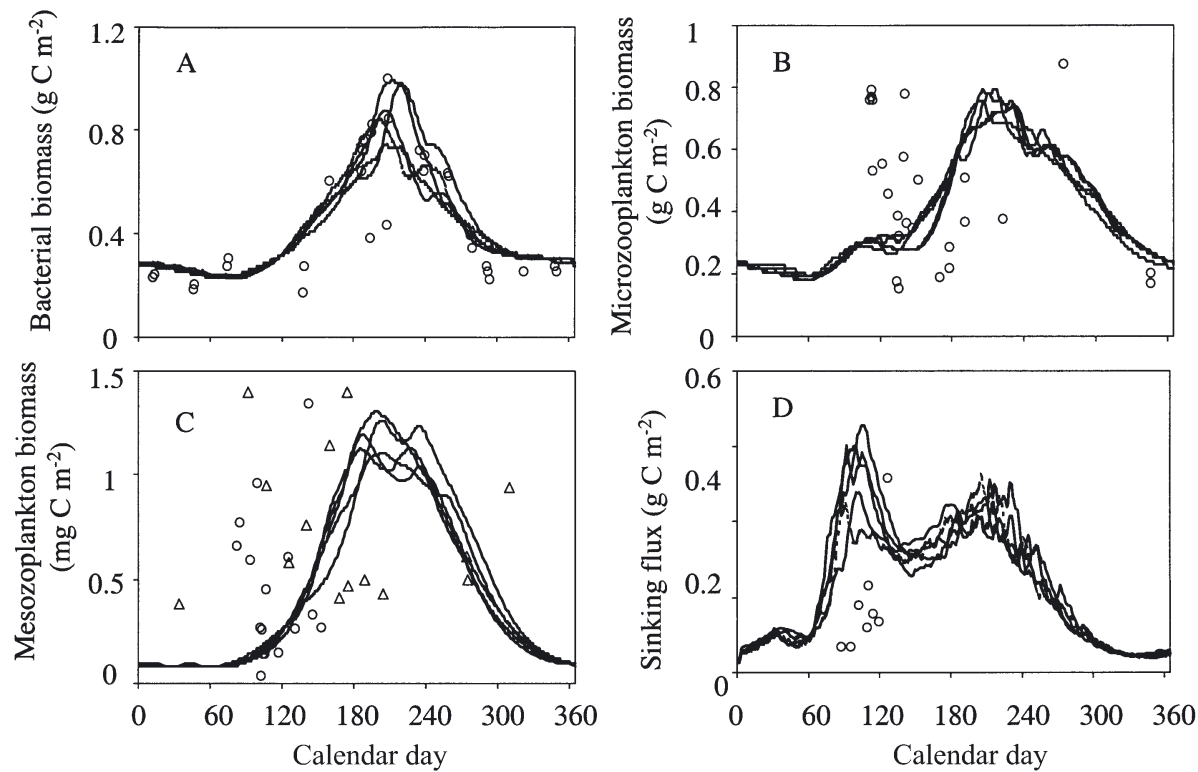

Fig. 5. Simulated (lines, all modeled years) and observed (circles) biomass of (A) bacteria, (B) microzooplankton and (C) mesozooplankton integrated over upper $50 \mathrm{~m}$, and (D) particle-sinking flux at $150 \mathrm{~m}$. Bacterial data were collected in 1992 , data for microzooplankton and particle-sinking flux in 1986, and mesozooplankton data (o) in 1988 and 1997 to $1998(\Delta)$ 


\section{Biological production}

The episodic vertical mixing events in early spring generated episodic nitrate supply to the euphotic zone, which accounted for $21 \%$ of the total annual upward flux of nitrate (Fig. 6E,F). Moreover, these episodic nitrate flux events showed pronounced interannual variability. In 1987 for example, there were considerably fewer upward flux events than in other years. Due to the reduced episodic nitrate supply in early spring, the total nitrate supply to the euphotic zone in 1987 was $10 \%$ lower than that in 1989 and 1990.
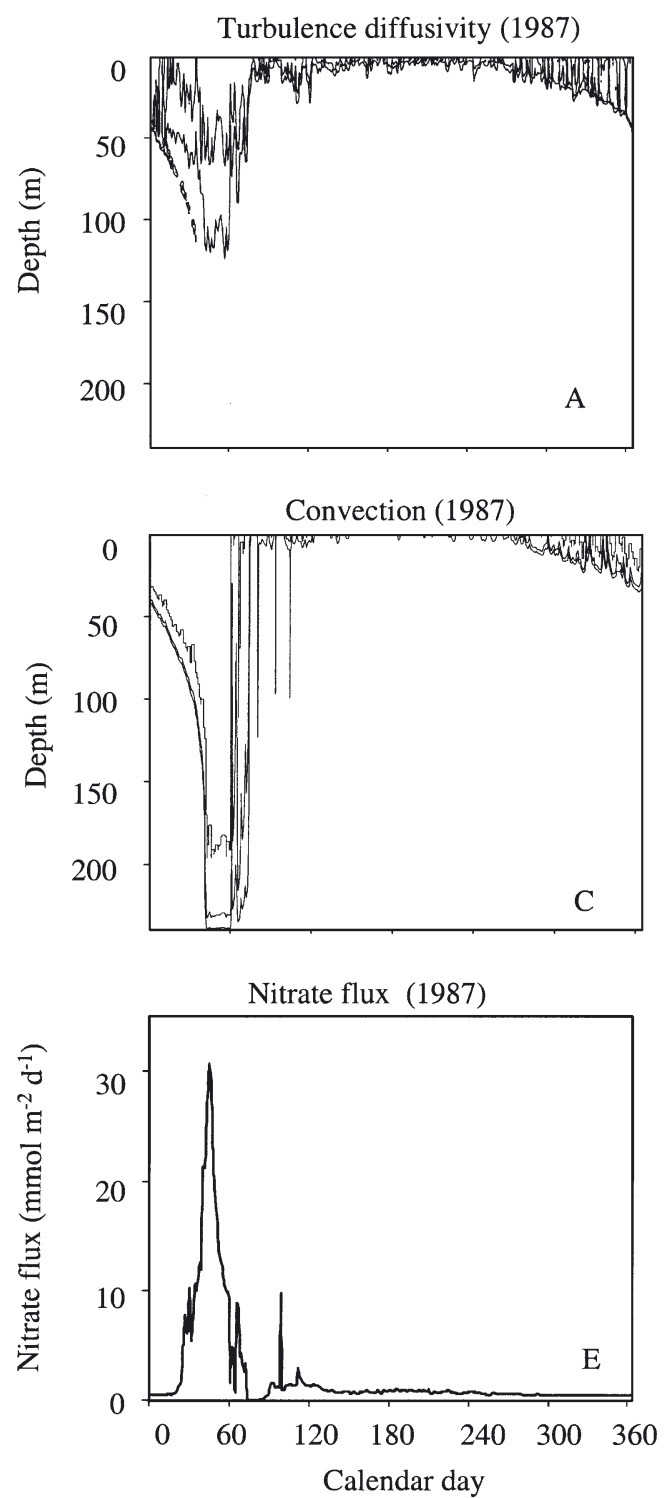

Simulated primary production ranged from $124 \mathrm{~g} \mathrm{C}$ $\mathrm{m}^{-2} \mathrm{yr}^{-1}$ in 1987 to $137 \mathrm{~g} \mathrm{C} \mathrm{m}^{-2} \mathrm{yr}^{-1}$ in 1989 (the sum of large and small phytoplankton production) (Table 2), comparable with remote sensing estimates in this region (100 to $140 \mathrm{~g} \mathrm{C} \mathrm{m}^{-2} \mathrm{yr}^{-1}$; Antoine et al. 1996, Behrenfeld \& Falkowski 1997). Model results suggest that small phytoplankton account for $69 \%$ of the total primary production and the $f$-ratio (nitrate-based over total primary production) has a mean value of 0.47 . A similar $f$-ratio value was obtained independently by Louanchi \& Najjar (2001), who based their calculation on nutrient and dissolved oxygen data from the region.
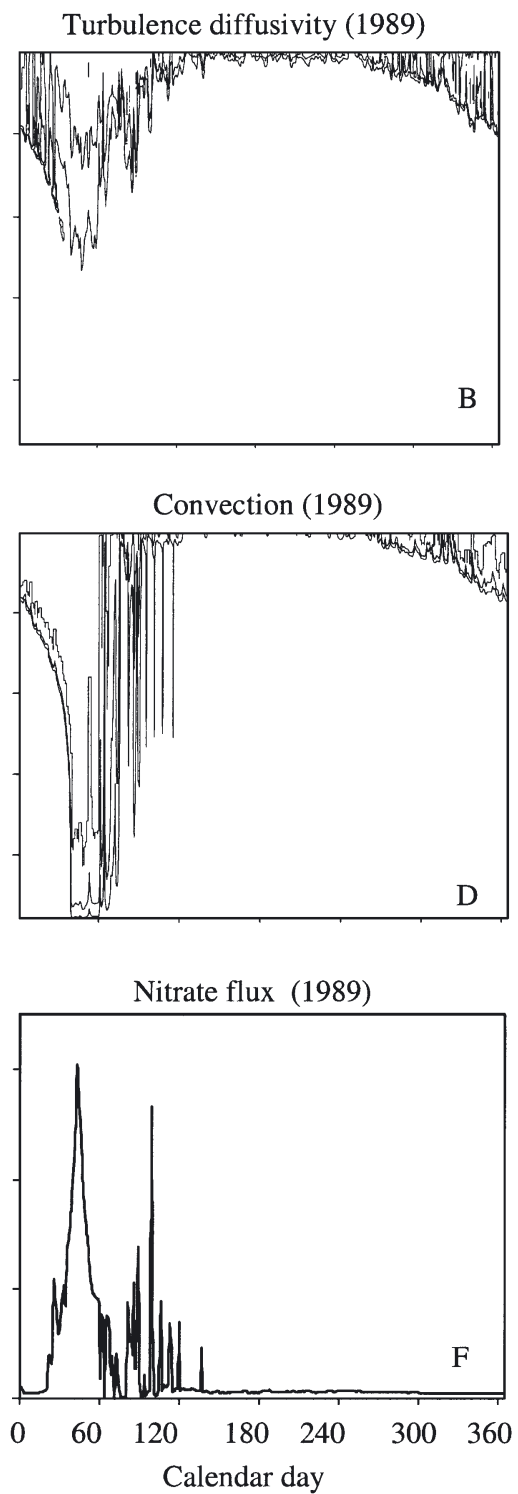

Fig. 6. $(\mathrm{A}, \mathrm{B})$ Turbulence diffusivity, $(\mathrm{C}, \mathrm{D})$ convection, and $(\mathrm{E}, \mathrm{F})$ nitrate upward flux across bottom of the euphotic zone for 1987 (lowest North Atlantic Oscillation [NAO] index among the 5 simulated years) and 1989 (highest NAO index). Isopleth values were 50, 200 and $1000 \mathrm{~m}^{2} \mathrm{~d}^{-1}$ (high-value above low-value isopleths) for turbulence diffusivity and convection, respectively 
Table 2. Simulated annual biological production $\left(\mathrm{g} \mathrm{C} \mathrm{m}^{-2} \mathrm{yr}^{-1}\right), f$-ratio of total primary production (dimensionless), particle sinking flux $\left(\mathrm{g} \mathrm{C} \mathrm{m}^{-2} \mathrm{yr}^{-1}\right)$, nitrate supply to euphotic zone $\left(\mathrm{molN} \mathrm{m} \mathrm{yr}^{-1}\right)$, and sensitivity analysis in which buoyancy flux-driven convective mixing was removed from the model

\begin{tabular}{|c|c|c|c|c|c|c|c|c|c|c|c|c|}
\hline \multirow{2}{*}{ Production and fluxes } & \multicolumn{6}{|c|}{ Standard simulation } & \multicolumn{6}{|c|}{ Sensitivity analysis } \\
\hline & 1986 & 1987 & 1988 & 1989 & 1990 & Mean & 1986 & 1987 & 1988 & 1989 & 1990 & Mean \\
\hline Large phytoplankton & 41.9 & 37.6 & 41.4 & 41.8 & 40.5 & 40.6 & 16.6 & 17.2 & 17.9 & 18.1 & 18.1 & 17.6 \\
\hline Small phytoplankton & 87.2 & 86.5 & 87.2 & 95.4 & 93.3 & 89.9 & 49.2 & 53.7 & 53.2 & 55.0 & 55.9 & 53.4 \\
\hline$f$-ratio & 0.49 & 0.46 & 0.47 & 0.47 & 0.46 & 0.47 & 0.36 & 0.35 & 0.35 & 0.34 & 0.35 & 0.35 \\
\hline Mesozooplankton & 9.5 & 10.3 & 9.6 & 10.5 & 10.6 & 10.1 & 3.1 & 4.1 & 3.9 & 4.0 & 4.4 & 3.9 \\
\hline Microzooplankton & 26.7 & 28.0 & 28.5 & 30.6 & 29.9 & 28.7 & 18.3 & 20.6 & 20.5 & 21.4 & 21.5 & 20.5 \\
\hline Bacteria & 13.6 & 14.8 & 14.4 & 15.7 & 15.6 & 14.8 & 10.0 & 10.8 & 10.8 & 11.1 & 11.0 & 10.7 \\
\hline Sinking flux & 42.1 & 40.5 & 42.7 & 44.7 & 44.5 & 42.9 & 16.5 & 17.9 & 18.2 & 18.5 & 19.0 & 18.0 \\
\hline $\mathrm{NO}_{3}^{-}$flux & 0.68 & 0.65 & 0.65 & 0.71 & 0.73 & 0.69 & 0.24 & 0.24 & 0.25 & 0.26 & 0.26 & 0.25 \\
\hline
\end{tabular}

Although the interannual variability in productivity of most of the biological pools was relatively low $(<15 \%)$, there was a strong correlation between total primary production and the NAO index (Fig. 7A). Small phytoplankton production had a strong correla-
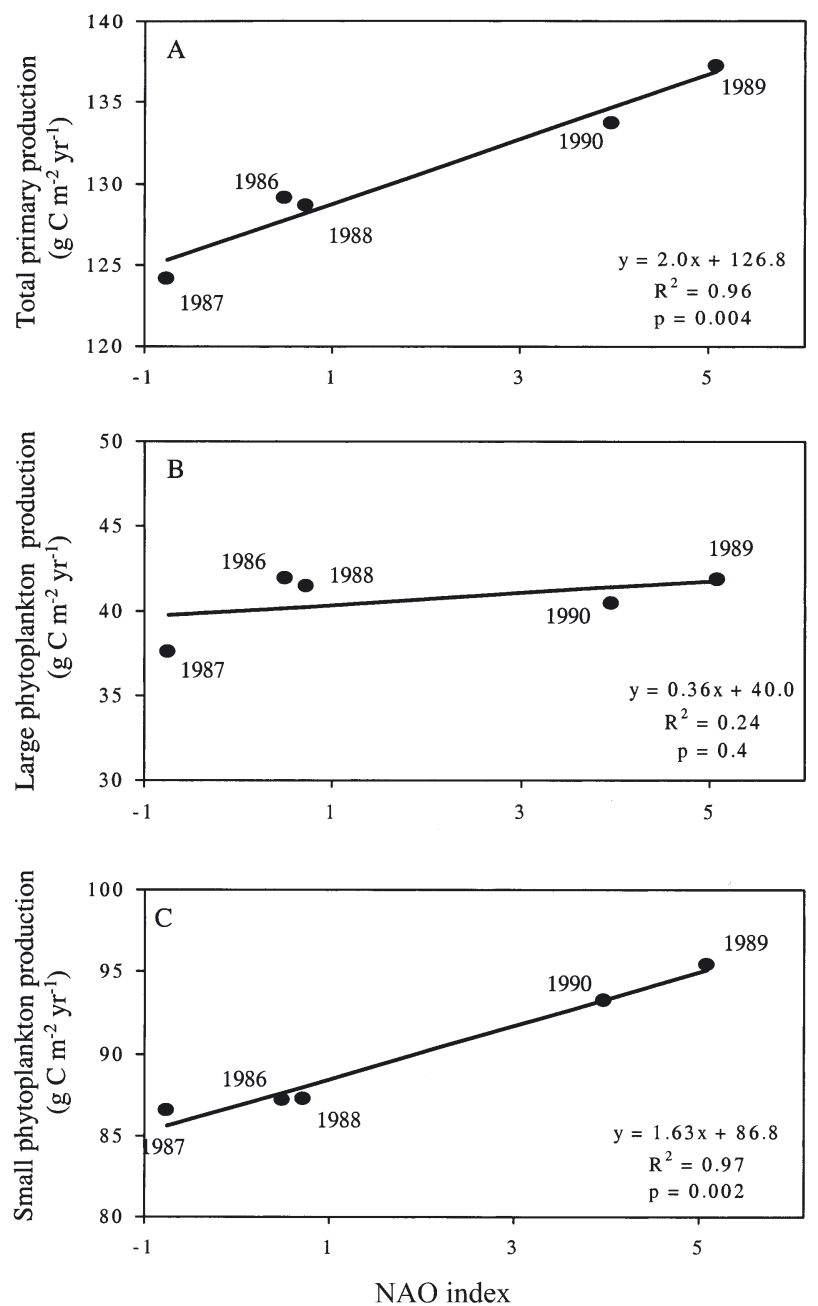

tion with the NAO index (Fig. 7C), whereas large phytoplankton production showed relatively low interannual variability (Fig. 7B). Similar positive correlations were also obtained between the NAO index and secondary productivity (Fig. 7D-F). The relationship
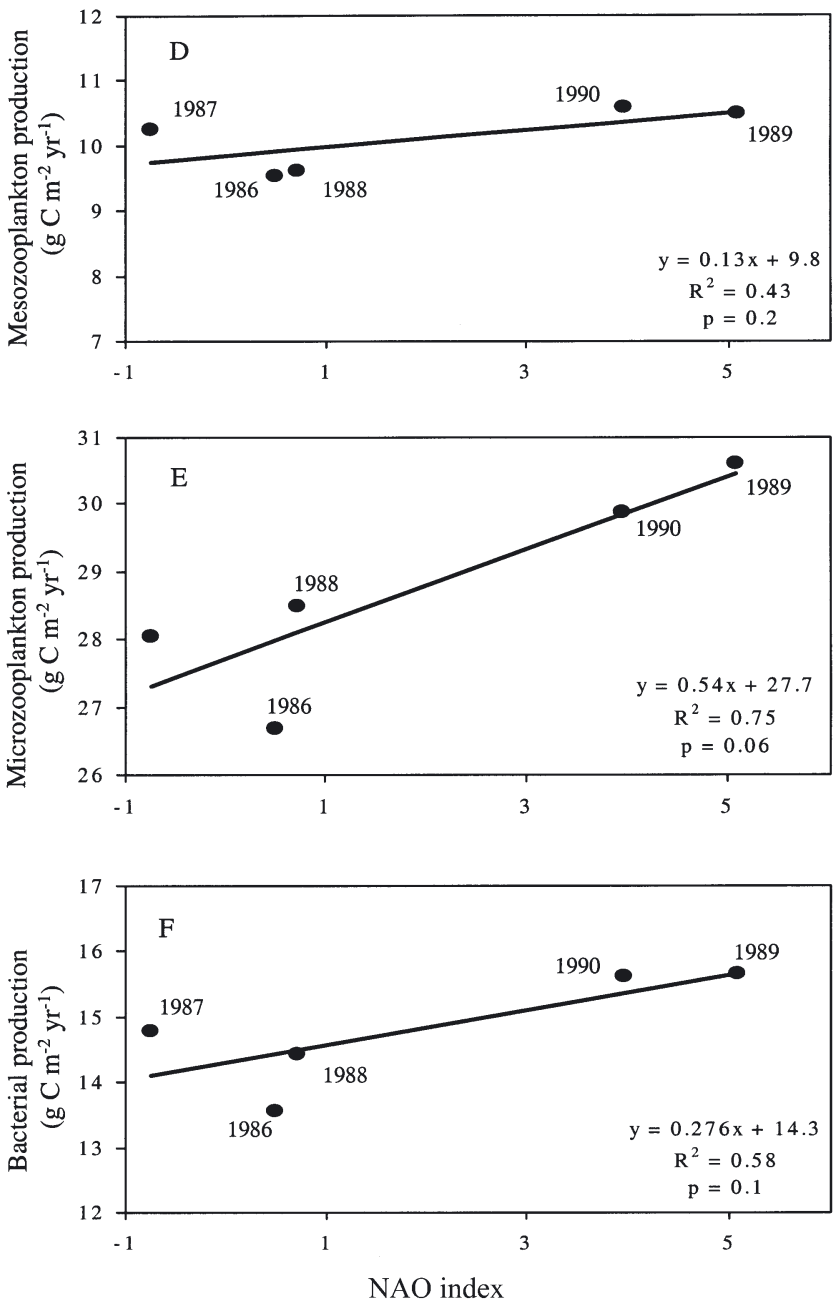

Fig. 7. Correlation between simulated annual production and NAO index 
between the NAO index and the productivity of microzooplankton was the strongest, while that with mesozooplankton production was the lowest, with the correlation with bacterial production intermediate between the two. Thus, the microbial food web (i.e. small phytoplankton, bacteria and microzooplankton) was more sensitive to climate variability than was the mesoplankton food web (i.e. large phytoplankton and mesozooplankton).

\section{DISCUSSION}

Climate change affects marine ecosystem function by altering physical dynamics and environmental interactions (Greene \& Pershing 2000, Miller \& Schneider 2000). Changes in wind stress and solar radiation are short-term variations, yet they can affect, for example, the timing and amplitude of the phytoplankton bloom and other seasonal patterns in biological activities. More important are long-term and large-scale effects, such as changes in seawater temperature, ice cover, sea level, freshwater discharge, salinity, upper ocean current fields, vertical mixing, deep convection, upwelling activity, thermohaline circulation and aeolian iron supply (Miller \& Schneider 2000, Hayes et al. 2001, IPCC 2001). These factors can influence ecosystem function on a variety of temporal and spatial scales. Vertical mixing, solar radiation and temperature are the major forcing factors in our model, so we essentially focus on these topics in our discussion.

\section{Vertical mixing}

Vertical mixing is of particular importance to the functioning of pelagic ecosystems. Both nutrient supply to the euphotic zone and the time-averaged irradiance experienced by the phytoplankton are controlled by vertical mixing. Vertical mixing in cold-ocean systems consists of wind-driven, eddy diffusivity and convective mixing caused by buoyancy flux. In hydrostatic general circulation models, the static instability resulting from heat loss at the sea surface is generally removed by geostrophic adjustment (Marotzke 1991, Yin \& Sarachik 1994, Rahmstorf 1995). Physical tracers such as salinity and temperature are conservative, so that any adjustment scheme which removes static instability can generate correct results for the physical dynamics of the water column. Biological-state variables (e.g. nutrients and phytoplankton) are not conserved quantities. Consequently, the geostrophic adjustment procedure is primarily important in physical-biological models. For example, implicit convection using a large mixing coefficient (e.g. $10 \mathrm{~m}^{2} \mathrm{~s}^{-1}$; Klinger et al. 1996, Marotzke \& Scott 1999) tends to overestimate nutrient supply to, and phytoplankton export from, the euphotic zone. On the other hand, simplified convective mixing, using bulk parameterization or averaging over unstable regions (Yin \& Sarachik 1994, Rudels et al. 1999), may underestimate nutrient supply and phytoplankton export. Biological modeling necessitates the explicit simulation of the convective mixing that we adapted in this study.

To assess the bias caused by the omission of vertical convection, we conducted a sensitivity analysis in which the biological model was forced only by winddriven turbulence diffusivity without buoyancy fluxdriven static convection. The results revealed significant decreases in nitrate supply and biological production in the euphotic zone. Compared to the standard simulation, nitrate supply to the euphotic zone decreased by $33 \%$ on average, and biological production decreased by $57 \%$ for large phytoplankton, $40 \%$ for small phytoplankton, $61 \%$ for mesozooplankton, $29 \%$ for microzooplankton and $27 \%$ for bacteria (Table 2). The mesoplankton food web was more affected than the microbial food web. This sensitivity analysis shows that the vertical convection coefficient needs to be adequately captured in physical-biological models to simulate cold-ocean ecosystems accurately.

\section{Timing of spring phytoplankton bloom}

Light intensity, vertical mixing and temperature are the 3 factors that are most frequently invoked to explain the onset of the spring phytoplankton bloom. For example, Strass \& Woods (1988) argued that the poleward propagation of the bloom follows outcropping of the $12^{\circ} \mathrm{C}$ isotherm with the seasonal heating of the ocean surface. Based on modeling analysis, Wroblewski et al. (1988) demonstrated that the progress of phytoplankton bloom in the open North Atlantic Ocean follows the shallowing of the mixed layer, whereas Townsend et al. (1994) showed that solar radiation regulated by cloudiness is the primary factor determining the timing of the phytoplankton bloom in the Gulf of Maine.

In our model, solar radiation, vertical mixing and seawater temperature are all explicitly simulated. To analyze their impact on the development of the phytoplankton bloom, we plotted the 3 variables against primary production over the first $90 \mathrm{~d}$ (January to March) of the 5 modeled years (Fig. 8). During this period, surface waters are nitrate-replete so that primary production is not nutrient-limited. PAR displayed the strongest correlation with primary production $\left(\mathrm{R}^{2}=\right.$ 

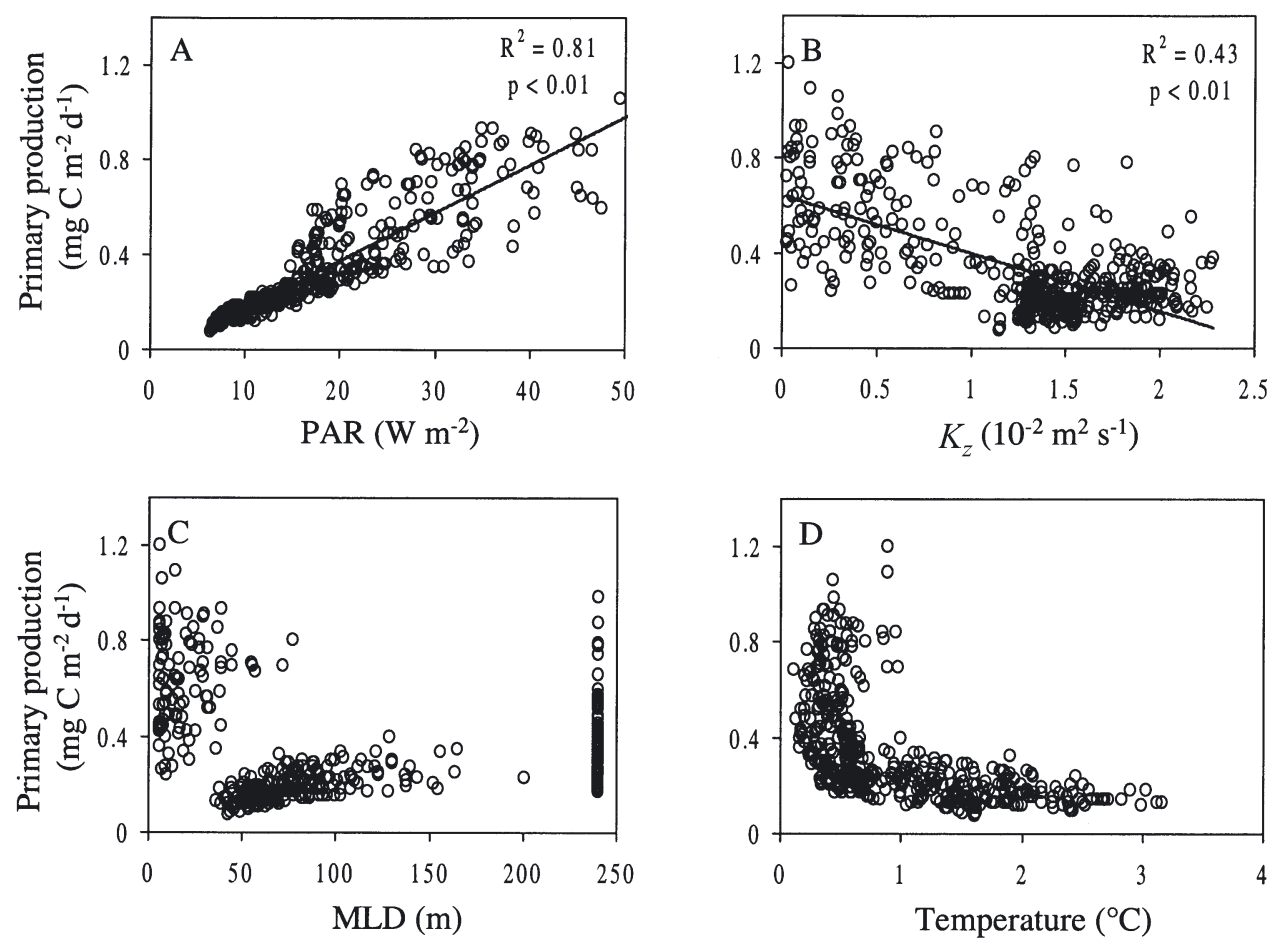

Fig. 8. Simulated relationship between primary production and (A) photosynthetically active radiation (PAR), (B) averaged vertical mixing coefficient $\left(K_{z}\right)$ in the water column, (C) mixed-layer depth (MLD) and (D) seawater temperature over first $90 \mathrm{~d}$ of each of the 5 simulated years

0.81, $\mathrm{n}=450$; Fig. 8A), followed by vertical mixing strength (Fig. 8B), whereas the mixed-layer depth showed no clear correlation with primary production (Fig. 8C) and high phytoplankton growth rate occurred in the low temperature range (Fig. 8D). At the PAR $\sim 15 \mathrm{~W} \mathrm{~m}^{-2}$ level, however, the primary production rates were noticeably higher than those predicted from the linear regression line (Fig. 8A), reflecting the light level at which the spring phytoplankton bloom starts. Riley (1967) suggested that the phytoplankton bloom starts when the depth-averaged irradiance within the mixed layer $(\bar{I})$ increases to ca. $21 \mathrm{~W} \times \mathrm{m}^{-2}$ :

$$
\bar{I}=\frac{I_{0}}{k z}\left(1-\mathrm{e}^{-k z}\right) \approx 21\left(\mathrm{~W} \times \mathrm{m}^{-2}\right)
$$

where $I_{0}$ is the total solar radiation at the sea surface, $k$ is the total attenuation coefficient in the water column and $z$ is the mixed-layer depth.

In our model, PAR was assumed to be $43 \%$ of total solar radiation, water attenuation $k_{\mathrm{w}}$ was $0.04 \mathrm{~m}^{-1}$ and chlorophyll attenuation $k_{\mathrm{c}}$ was $0.03 \times$ [chl] where [chl] is chlorophyll concentration in $\mathrm{mg} \mathrm{chl} \mathrm{m}^{-3}$ ) and the carbon:chlorophyll ratio was 50. Generally, the simulated phytoplankton bloom occurred when the mixed-layer depth was ca. $30 \mathrm{~m}$ (Fig. 8C) and the background phytoplankton biomass was at the $2 \mathrm{mmol} \mathrm{C} \mathrm{m}^{-3}$ level (i.e. ca. $24 \mathrm{mg} \mathrm{C} \mathrm{m}^{-3}$ before the bloom). With the above parameter values, PAR at $15 \mathrm{~W} \mathrm{~m}^{-2}$ at the sea surface corresponds to $\bar{I}=17 \mathrm{~W} \mathrm{~m}^{-2}$, slightly lower than the value suggested by Riley (1967).

The vertical mixing strength averaged over the entire water column (to the bottom, i.e. $240 \mathrm{~m}$ ) was also significantly negatively correlated $(\mathrm{p}<0.01)$ with primary production (Fig. 8B). Primary production is generally low when the averaged vertical mixing coefficient is $>1.3 \times 10^{-2} \mathrm{~m}^{2} \mathrm{~s}^{-1}$. Multivariate regression analysis indicated that PAR and the vertical mixing coefficient together explain $88 \%$ of the total variance in the primary production rate under nutrient-replete conditions, of which PAR accounts for $58 \%$ while the vertical mixing coefficient accounts for $30 \%$. However, the relative importance of light and vertical mixing strength in determining the timing of the phytoplankton bloom may differ from region to region. In a previous study in the Labrador Sea, our model showed that vertical mixing strength is the major factor controlling the phytoplankton bloom (Tian et al. 2003). In coastal regions where the water column is shallower than the critical depth, light becomes the dominating factor controlling the development of the phytoplankton bloom (Townsend et al. 1994).

Our simulated results suggest that phytoplankton biomass accumulated when the mixed-layer depth was 
$<40 \mathrm{~m}$ (Fig. 8C). There are many exceptions, however. High primary production also occurred when the mixed layer was deep. In fact, the mixed-layer depth is not always a metric of the vertical mixing strength. When both wind and heat flux are low, vertical mixing is limited whether the water column is stratified or homogeneous. Under such neutral conditions, phytoplankton biomass can accumulate even though the mixed layer is deep (Townsend et al. 1994).

Our results reveal that the initiation of the spring phytoplankton bloom in Conception Bay is independent of temperature. This is in agreement with many years of observations in the bay which indicate that the spring bloom begins when the water column is essentially isothermal and below $0^{\circ} \mathrm{C}$ (Pomeroy et al. 1991, Ostrom et al. 1997, Stead \& Thompson 2003). PAR, vertical mixing strength and seawater temperature are all forcing variables for biological growth rates in the model. However, the simulated results show that not all the biological rates are equally responsive to these different forcing functions. For example, while the phytoplankton growth rate was formulated as an exponential function of temperature in the model (Eq. 3), the simulated community phytoplankton growth rate was almost independent of temperature, with high growth rates occurring at low temperature ranges (Fig. 8C). The similarity between simulations and field observations indicates that the model successfully simulates the combined effects of various forcing variables and trophic dynamics.

\section{Pelagic-benthic energy flow}

The sinking flux of biogenic detritus to the bottom represents an average of $33 \%$ of the annual primary production. The flux of sinking particulate matter has a bimodal distribution, with the highest value during the spring phytoplankton bloom and a second peak in late summer (Fig. 5D). The flux of sinking biogenic detritus during the spring bloom (March to May) accounted for an average of $38 \%$ of the annual sinking flux, while that in summer (July to September) accounted for $36 \%$ (seasonal sinking flux in Fig. 9 divided by annual sinking flux in Table 2). However, the phytoplankton biomass in the euphotic zone had only 1 peak during the spring bloom. Neither the simulations nor field observations showed a second maximum of phytoplankton biomass in summer at the time of the sinking of biogenic detritus. According to the model, there is a second productive season in late summer and early fall. Because of the dominance of the microbial food web in summer, the second productive period was not reflected in an increase in the standing stock of phytoplankton in
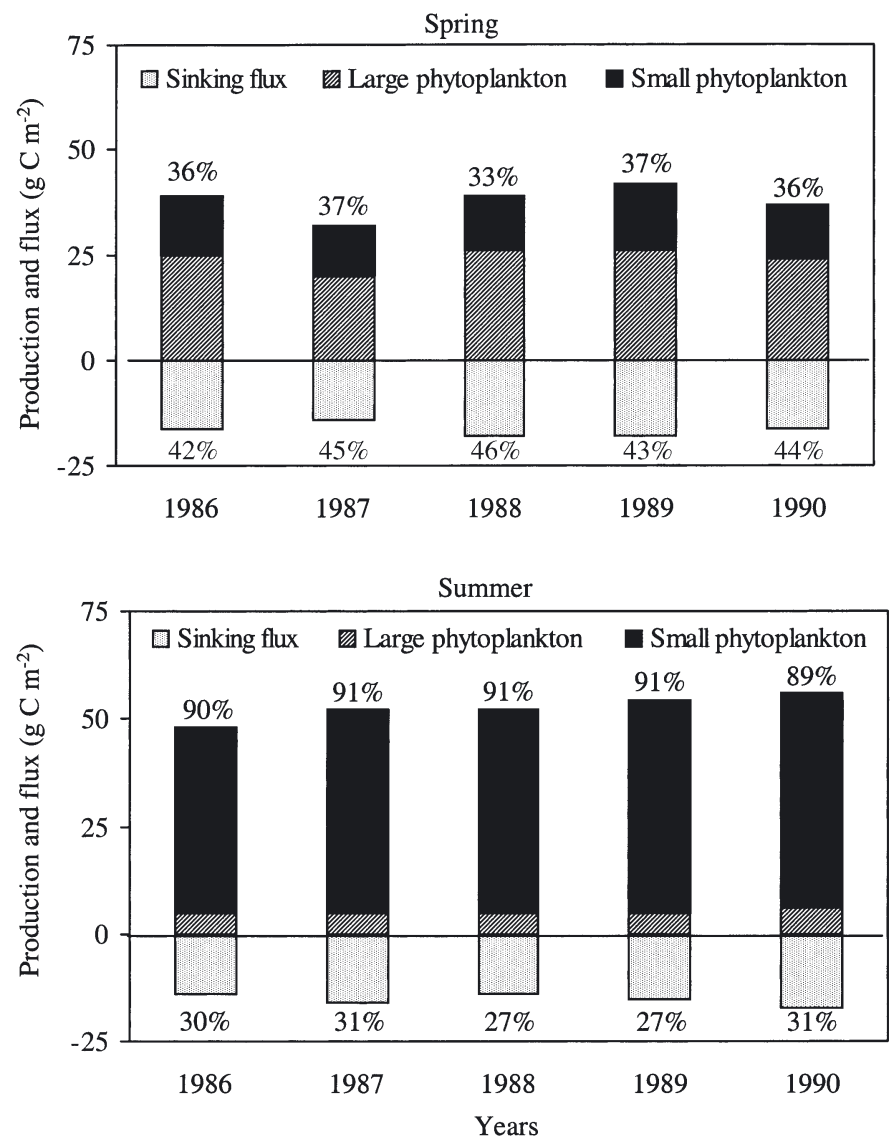

Fig. 9. Integrated primary production and particulate sinking flux from euphotic zone during spring phytoplankton bloom season (March to May, upper graph) and during summer productive season (July to September, lower graph). Percentages above bars: $\%$ small phytoplankton production contributed to total primary production; percentages below bars: \% particulate sinking flux compared to total primary production

surface waters. Production of small phytoplankton accounted for $90 \%$ of the total primary production in summer, but only $36 \%$ in spring (Fig. 9). During the spring bloom, $44 \%$ of the total primary production was exported from the euphotic zone while $29 \%$ was exported in summer. The high efficiency in energy transfer from the pelagic to the benthic ecosystem in spring was due to the dominance of large phytoplankton. Based on the phytoplankton composition and the particulate sinking flux, $56 \%$ of large phytoplankton production was exported from the euphotic zone versus $26 \%$ of small phytoplankton. As the simulation of the particulate sinking flux is not constrained during summer, when microbial production is higher (Fig. 5D), the uncertainty of the export efficiency of the microbial food web should be higher than that for the mesoplankton food web. 


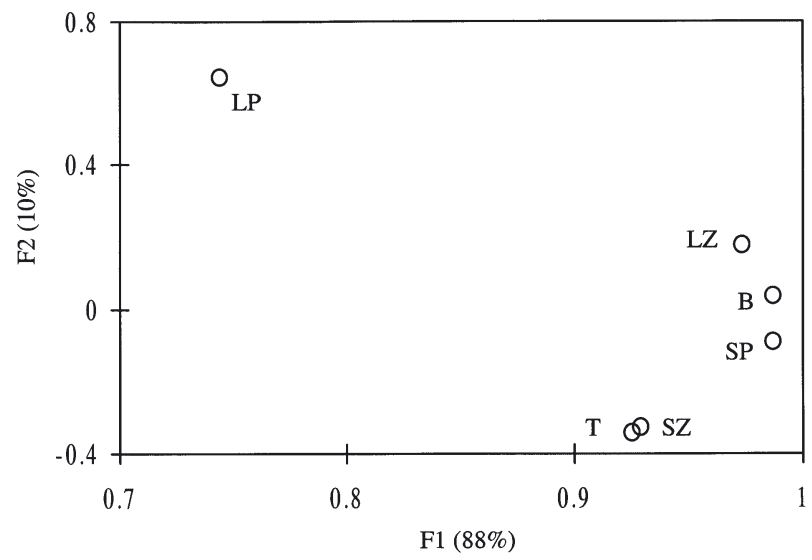

Fig. 10. Principal components analysis of biological production and seawater temperature during the summer productive season (July to September). B: Bacterial production; LP: large phytoplankton production; SP: small phytoplankton production; LZ: mesozooplankton production; SZ: microzooplankton production; T: seawater temperature. Small phytoplankton, microzooplankton and bacteria were significantly correlated with $\mathrm{T}(\mathrm{p}<0.05)$ and mesozooplankton were correlated with $\mathrm{T}$ significantly at $\mathrm{p}=0.07$, but there was no significant correlation between large phytoplankton and $\mathrm{T}$

\section{Interannual variability in biological production and climate forcing}

We found significant correlation between the NAO index and the production rates of several of the simulated biological pools, implying that the large-scale climate regime has an impact on the Conception Bay ecosystem. We explore below the possible mechanisms connecting climate variability and biological production.

The simulated primary production was lower by $7.2 \mathrm{~g} \mathrm{C} \mathrm{m}^{-2}$ during the spring production in 1987 than that in the other years simulated. Due to the relatively higher air temperature and lower wind velocity in spring 1987, the vertical mixing strength was relatively lower than in the same period of the other years. Consequently, the upward flux of nitrate and the resultant primary production was lower during the spring phytoplankton bloom in 1987 than in the other years. The nitrate supply to the euphotic zone from March through May in 1987 was 0.058 mol N $\mathrm{m}^{-2}$ lower than the long-term average of the other years, which theoretically should lead to a reduction in primary production by $4.6 \mathrm{~g} \mathrm{C} \mathrm{m}^{-2}$. Thus, the difference in the nitrate upward flux could account for $64 \%$ of the decrease in primary production in 1987 , and other controlling factors could account for the remainder.

Light is an important factor controlling the onset of the spring phytoplankton bloom (Riley 1967,
Townsend et al. 1994). Because of cloudy weather in the spring of 1987, solar radiation reaching the sea surface was relatively lower than in the rest of the modeled years. The average PAR from January through March was $15.9 \mathrm{~W} \mathrm{~m}^{-2}$ in 1987, whereas the mean for the other 4 simulated years was $18.7 \mathrm{~W}$ $\mathrm{m}^{-2}$. Solar radiation was particularly low in March 1987 (when the phytoplankton bloom typically begins to develop), $21 \%$ lower than values for the other simulated years (22.5 vs $\left.28.6 \mathrm{~W} \mathrm{~m}^{-2}\right)$. This reduction in solar radiation may account for some of the remaining deficit in primary production during the spring of 1987.

Integrated quarterly primary production in summer (July to September) is larger than that during the spring bloom (March to May). We have shown that the phytoplankton bloom occurs at the low temperature range in Conception Bay. In summer, however, the productivities of all the components of the microbial system (e.g. small phytoplankton, microzooplankton and bacteria) were all significantly $(p<0.05)$ correlated with temperature (Fig. 10). Mesozooplankton production was also correlated with temperature to some extent, whereas large phytoplankton production was not. Thus, temperature influences primary production only indirectly in spring (by changing the vertical mixing strength) and more directly in summer by affecting the metabolic rates of members of the microbial food web. We conclude that the strong linkage between the NAO index and ecosystem dynamics in Conception Bay results from the combined effects of variability in solar radiation, vertical mixing strength and water temperature.

The simulated variability in biological production and energy flows resulted from local meteorological forcing only. Variations due to changes in the 3D current field and hydrological properties were not simulated in this study. Biological processes that are not parameterized in the model are also a source of uncertainty in the model predictions, such as zooplankton vertical migration and the combined limiting effects of multiple nutrients. Prediction of climate forcing on marine ecosystems over large spatial scales necessitates improvement in parameterization of both physical and biological dynamics.

Acknowledgements. The authors thank Dr. N. Choi for providing unpublished data on mesozooplankton for this study.

\section{LITERATURE CITED}

Antoine D, Andre JM, Morel A (1996) Ocean primary production. 2. Estimation at global scale from satellite (coastal zone color scanner) chlorophyll. Global Biogeochem Cycles $10: 57-69$ 
Archer D, Emerson S, Powell T, Wong CS (1993) Numerical hindcasting of sea surface $\mathrm{pCO}_{2}$ at Weather Station Papa. Prog Oceanogr 32:319-351

Barnett TP, Pierce DW, Schnur R (2001) Detection of anthropogenic climate change in the world's oceans. Science 292:270-274

Behrenfeld MJ, Falkowski PG (1997) Photosynthetic rates derived from satellite-based chlorophyll concentration. Limnol Oceanogr 42:1-20

Budge SM, Parrish CC (1998) Lipid biogeochemistry of plankton, settling matter and sediments in Trinity Bay, Newfoundland. II. Fatty acids. Org Geochem 29: $1547-1559$

Choe N, Deibel D (2000) Seasonal vertical distribution and population dynamics of the chaetognath Parasagitta elegans in the water column and hyperbenthic zone of Conception bay, Newfoundland. Mar Biol 137:847-856

Conover RJ, Huntley M (1991) Copepods in ice-covered seas - distribution, adaptations to seasonally limited food, metabolism, growth patterns and life cycle strategies in polar seas. J Mar Syst 2:1-41

Coyle KO, Paul AJ, Ziemann DA (1990) Copepod population during the spring bloom in an Alaskan subarctic embayment. J Plankton Res 12:759-797

Deibel D (1986) Feeding mechanism and house of the appendicularian Oikopleura vanhoeffeni. Mar Biol 93: 429-436

DeYoung B, Sanderson B (1995) The circulation and hydrography of Conception Bay, Newfoundland. Atmos-Ocean 33:135-162

DeYoung B, Otteron T, Greatbatch RJ (1993) The local and non local response of Conception Bay to wind forcing. J Phys Oceanogr 23:2636-2649

Durbin EG, Gilman SL, Cambel RG, Durbin AG (1995) Abundance, biomass, vertical migration and estimated development rate of the copepod Calanus finmarchicus in the southern Gulf of Maine during late spring. Contin Shelf Res 15:571-591

Edwards M, Beaugrand G, Reid PC, Rowden AA, Jones MB (2002) Ocean climate anomalies and the ecology of the North Sea. Mar Ecol Prog Ser 239:1-10

Francis RC, Hare SR, Hollowed AB, Wooster WS (1998) Effects of interdecadal climate variability on the oceanic ecosystems of the NE Pacific. Fish Oceanogr 7:1-21

Greene CH, Pershing AJ (2000) The response of Calanus finmarchicus populations to climate variability in the Northwest Atlantic: basin-scale forcing associated with the North Atlantic Oscillation. ICES J Mar Sci 57: 1536-1544

Hayes ML, Bonaventura J, Mitchell TP, Prospero JM, Shinn EA, Van Dolah F, Barber RT (2001) How are climate and marine biological outbreaks functionally linked? Hydrobiologia 460:213-220

Head EH, Harris LR, Campbell RW (2000) Investigations on the ecology of Calanus spp. in the Labrador Sea. I. Relationship between the phytoplankton bloom and reproduction and development of Calanus finmarchicus in spring. Mar Ecol Prog Ser 193:53-73

Huntley ME, Lopez DG (1992) Temperature-dependent production of marine copepods: a global synthesis. Am Nat 140:201-242

Hurell JW (1995) Decadal trends in the North Atlantic Oscillation: regional temperature and precipitation. Science 269:676-679

IPCC (Intergovernmental Panel on Climate Change) (2001) Climate change 2001. In: Houghton JT, Ding Y, Griggs DJ, Noguer M, van der Linden PJ, Dai X, Maskell K, Johnson
CA (eds) The 2001 Report of the Scientific Assessment Working Group of the Intergovernmental Panel on Climate Change (IPCC). Cambridge Press, London, p 204-237

Iribarne JV, Godson WL (1981) Atmospheric thermodynamics. D Reidel, Boston

Karl DM, Bidigare RR, Letelier RM (2001) Long-term changes in plankton community structure and productivity in the North Pacific Subtropical Gyre: the domain shift hypothesis. Deep-Sea Res II 48:1449-1470

Klinger BA, Marshall J, Send U (1996) Representation of convective plumes by vertical adjustment. J Geophys Res C Oceans 101:18175-18182

Kuhn W, Radach G (1997) A one-dimensional physicalbiological model study of the pelagic nitrogen cycling during the spring bloom in the northern North Sea (FLEX '76). J Mar Res 55:687-734

Louanchi F, Najjar RG (2001) Annual cycles of nutrients and oxygen in the upper layers of the North Atlantic Ocean. Deep-Sea Res II 48:2155-2171

Marotzke J (1991) Influence of convective adjustment on the stability of the thermohaline circulation. J Phys Oceanogr 21:903-908

Marotzke J, Scott JR (1999) Convective mixing and the thermohaline circulation. J Phys Oceanogr 29:2962-2970

Martin PJ (1985) Simulation of the mixed layer at OWS November and Papa with several models. J Geophys Res C Oceanogr 90:903-916

Mathieu T, DeYoung B (1995) Application of a mixed layer model to the inner Newfoundland shelf. J Geophys Res C Oceanogr 100:921-936

Mellor GL, Yamada T (1982) Development of a turbulence closure model for geophysical fluid problems. Rev Geophys Space Phys 20:851-875

Miller AJ, Schneider N (2000) Interdecadal climate regime dynamics in the North Pacific Ocean: theories, observations and ecosystem impacts. Prog Oceanogr 47:355-379

Myrhaug D, Slaattelid OH (1998) Bottom shear stress and velocity profiles in stratified tidal planetary boundary layer flow from similarity theory. J Mar Syst 14:167-180

Niiler PP, Kraus EB (1977) One-dimensional models of the upper ocean. In: Kraus ED (ed) Modeling and prediction of the upper layers of the ocean. Pergamon Press, New York, p 143-172

Ostrom NE, Macko SA, Deibel D, Thompson RJ (1997) Seasonal variation in the stable carbon and nitrogen isotope biogeochemistry of a coastal cold-ocean environment. Geochim Cosmochim Acta 61:2929-2942

Parker RA (1993) Dynamic models for ammonium inhibition of nitrate uptake by phytoplankton. Ecol Model 66: $113-120$

Parkinson CL, Washington WM (1979) A large-scale numerical model of sea ice. J Geophys Res C Oceanogr 84: 311-337

Petrie B, Loder JW, Akenhead S, Lazier J (1991) Temperature and salinity variability on the eastern Newfoundland shelf: the annual harmonic. Atmos-Ocean 29:14-36

Pingree RD, Pennycuick L (1975) Transfer of heat, fresh water and nutrients through the seasonal thermocline. J Mar Biol Assoc UK 55:261-274

Planque B, Fromentin JM (1996) Calanus and environment in the Eastern North Atlantic. I. Spatial and temporal patterns of C. finmarchicus and C. helgolandicus. Mar Ecol Prog Ser 134:101-109

Platt T, Gallegos CL, Harrison WG (1980) Photoinhibition of photosynthesis in natural assemblages of marine phytoplankton. J Mar Res 38:687-701 
Pollard D, Batteen ML, Yan YJ (1983) Development of a simple upper-ocean and sea-ice model. J Phys Oceanogr 13:754-768

Polovina JJ, Mitchum GT, Graham NE, Craig MP, Demartini EE, Flint EN (1994) Physical and biological consequences of a climate event in the central North Pacific. Fish Oceanogr 3:15-21

Pomeroy LR, Wiebe WJ, Deibel D, Thompson RJ, Rowe GT, Pakulski JD (1991) Bacterial responses to temperature and substrate concentration during the Newfoundland spring bloom. Mar Ecol Prog Ser 75:143-159

Quevedo M, Anadon R (2000) Spring microzooplankton composition, biomass and potential grazing in the central Cantabrian coast (southern Bay of Biscay). Oceanol Acta 23:297-309

Rahmstorf S (1995) Multiple convection patterns and thermocline flow in an idealized OGGM. J Climatol 8: 3028-3039

Redden AM (1994) Grazed-mediated chloropigment degradation and the vertical flux of spring bloom production in Conception Bay, Newfoundland. PhD thesis, Memorial University, St. John's

Riley GA (1967) The plankton in estuaries. Estuaries 83: 316-326

Rudels B, Friedrich HJ, Hainbucher D, Lohmann G (1999) On the parameterization of oceanic sensible heat loss to the atmosphere and to ice in an ice-covered mixed layer in winter. Deep-Sea Res II 46:1385-1425

Sharples J, Tett P (1994) Modelling the effect of physical variability on the midwater chlorophyll maximum. J Mar Res 52:219-238

Shindell DT, Miller RL, Schmidt GA, Pandolfo L (1999) Simulation of recent northern winter climate trends by greenhouse-gas forcing. Nature 399:452-455

Stead RA, Thompson RJ (2003) The effect of the sinking spring bloom on digestive processes of the cold-water protobranch Yoldia hyperborea. Limnol Oceanogr 48:157-167

Strass V, Woods JA (1988) Horizontal and seasonal variation of density and chlorophyll profiles between the Azores and Greenland. In: Rothschild BJ (ed) Toward a theory of biological-physical interaction in the World Ocean. D Reidel, Boston, p 113-136

Sugimoto T, Tadokoro K (1998) Interdecadal variations of plankton biomass and physical environment in the North Pacific. Fish Oceanogr 7:289-299

Tian RC, Vézina AF, Legendre L, Ingéram RG and 7 others (2000) Effects of pelagic food-web interactions and nutrient remineralization on the biogeochemical cycling of carbon: a modeling approach. Deep-Sea Res II 47: $637-662$

Tian RC, Vézina AF, Starr M, Saucier F (2001) Seasonal dynamics of coastal ecosystems and export production at high latitudes: a modeling study. Limnol Oceanogr 46: 1845-1859

Tian RC, Vézina AF, Deibel D, Rivkin RB (2003) Sensitivity of biogenic carbon export to ocean climate in the Labrador Sea, a deep-water formation region. Global Biogeochem Cycles 17(4):1090

Townsend DW, Cammen LM, Holligan PM, Campbell DE, Pettigrew N (1994) Causes and consequences of variability in the timing of spring phytoplankton blooms. DeepSea Res I 41:747-765

Umoh JU, Loder JW, Petrie B (1995) The role of air-sea heat fluxes in annual and interannual ocean temperature variability on the eastern Newfoundland shelf. Atmos-Ocean 33:531-568

Verity PG (1981) Effects of temperature, irradiance, and daylength on the marine diatom Leptocylindrus Danicus Cleve. I. Photosynthesis and cellular composition. J Exp Biol Ecol 55:79-91

Warrach K (1998) Modelling the thermal stratification in the North Sea. J Mar Syst 14:151-165

Wroblewski JS, Sarmiento JL, Flierly GL (1988) An ocean basin scale model of plankton dynamics in the North Atlantic. 1. Solutions for the climatological oceanographic conditions in May. Global Biogeochem Cycles 2:199-218

Xing J, Davies AM (1995) Application of three dimensional turbulence energy models to the determination of tidal mixing and currents in a shallow sea. Prog Oceanogr 35: 153-205

Yentsch CS, Menzel DW (1963) A method for the determination of phytoplankton, chlorophyll, and pheophytin by fluorescence. Deep-Sea Res I 10:221-231

Yin FL, Sarachik ES (1994) An efficient convective adjustment scheme for ocean general circulation models. J Phys Oceanogr 24:1425-1429 
Appendix 1. Physical model simulating hydrodynamics of water column

The vertical turbuence diffusivity $\left(K_{Z}\right)$ was determined by the Mellor-Yamada level 2.5 turbulence closure scheme (Mellor \& Yamada 1982):

$$
\begin{gathered}
\frac{\partial}{\partial t}\left(\frac{q^{2}}{2}\right)=\frac{\partial}{\partial z}\left(K_{q} \frac{\partial}{\partial z}\left(\frac{q^{2}}{2}\right)\right)+K_{M}\left[\left(\frac{\partial u}{\partial z}\right)^{2}+\left(\frac{\partial v}{\partial z}\right)^{2}\right]-K_{z}\left(\frac{g}{\rho} \frac{\partial \rho}{\partial z}\right)-\frac{q^{3}}{B_{1} l} \\
l=\frac{k h}{a+k h / l_{0}} ; l_{0}=\gamma \frac{\int_{h_{0}}^{H} h q d h}{\int_{h_{0}}^{H} q \mathrm{~d} h}
\end{gathered}
$$

where $\left(q^{2} / 2\right)$ is the turbulence kinetic energy (TKE), $q$ is the turbulence velocity scale, $K_{q}, K_{M}$ and $K_{z}\left(\mathrm{~m}^{2} \mathrm{~s}^{-1}\right)$ are coefficients of turbulence diffusivity for TKE, momentum and tracers, respectively, $u$ and $V$ are current in $x$ (west-east) and $y$ (south-north) directions $\left(\mathrm{m} \mathrm{s}^{-1}\right), g$ is gravity force $\left(9.8 \mathrm{~m} \mathrm{~s}^{-2}\right), \rho$ is water density $\left(\mathrm{kg} \mathrm{m}^{-3}\right), z$ is depth $(\mathrm{m}), h$ is the distance from the bottom $(\mathrm{m}), H$ is the total water depth $(\mathrm{m}), l$ is the vertical-mixing length scale, $B_{1}=16.6, k=0.4$ (von Karman's constant), $\gamma=0.1$ and $h_{0}=$ 1 (roughness length at the bottom; Sharples \& Tett 1994, Xing \& Davies 1995). The terms on the right-hand side of Eq. (A1) represent TKE diffusion, shear production, buoyancy production and TKE dissipation, respectively. The turbulence diffusivity coefficients $K_{q}, K_{M}$ and $K_{z}$ were calculated as

$$
\begin{gathered}
K_{M}=S_{M} l q_{i} \quad K_{z}=S_{H} l q_{;} \quad K_{q}=0.2 l q \\
S_{M}=B_{1}^{-\frac{1}{3}} \frac{\left(1-\frac{R_{f}}{R_{f c}}\right)\left(1-\frac{R_{f}}{R_{f 1}}\right)}{\left(1-R_{f}\right)\left(1-\frac{R_{f}}{R_{f 2}}\right)} ; S_{H}=B_{1}^{-\frac{1}{3}} \frac{\left(1-\frac{R_{f}}{R_{f c}}\right)}{\left(1-R_{f}\right)} \\
R_{f}=0.5\left(b-\sqrt{b^{2}-4 R_{f_{1}} R_{i}}\right) ; \quad b=R_{f 1}+\frac{R_{f 1}}{R_{f 2}} R_{i ;} \\
R_{i}=\frac{\frac{g}{\rho}\left(\frac{\partial \rho}{\partial z}\right)}{\left(\frac{\partial u}{\partial z}\right)^{2}+\left(\frac{\partial v}{\partial z}\right)^{2}}
\end{gathered}
$$

where $R_{f 1}=0.245, R_{f 2}=0.223, \mathrm{R}_{f C}=0.19, \mathrm{~S}_{M}$ and $\mathrm{S}_{H}$ are stability functions and $R_{i}$ is the gradient Richardson number (Martin 1985, Sharples \& Tett 1994, Warrach 1998). Current ( $u$ and $v$ ), temperature $(T)$ and salinity $(S)$ were calculated by the following equations:

$$
\begin{gathered}
\frac{\partial u}{\partial t}=g\left(\eta_{\mathrm{M} 2}^{x}+\eta_{M f}^{x} \sin \left(\frac{2 \pi\left(t-\varphi_{\mathrm{SN}}\right)}{T_{\mathrm{SN}}}\right)\right) \sin \left(\frac{2 \pi\left(t-\varphi_{\mathrm{M} 2}\right)}{T_{\mathrm{M} 2}}\right)+\frac{\partial}{\partial z}\left(K_{M}(z) \frac{\partial u}{\partial z}\right)+f v-\varepsilon u \\
\frac{\partial v}{\partial t}=g\left(\eta_{\mathrm{M} 2}^{y}+\eta_{M f}^{y} \sin \left(\frac{2 \pi\left(t-\varphi_{\mathrm{SN}}\right)}{T_{\mathrm{SN}}}\right)\right) \sin \left(\frac{2 \pi\left(t-\varphi_{\mathrm{M} 2}\right)}{T_{\mathrm{M} 2}}\right)+\frac{\partial}{\partial z}\left(K_{M}(z) \frac{\partial V}{\partial z}\right)-\begin{array}{r}
f u-\varepsilon V \\
(\mathrm{~A} 7)
\end{array} \\
\frac{\partial T}{\partial t}=\frac{\partial}{\partial z}\left(\left(K_{z}(z)\right) \frac{\partial T}{\partial z}\right)+\frac{1}{\rho c_{p}} \frac{\partial I}{\partial z} \\
\frac{\partial S}{\partial t}=\frac{\partial}{\partial z}\left(\left(K_{z}(z)\right) \frac{\partial S}{\partial z}\right)
\end{gathered}
$$

where $\eta_{M 2}^{x}, \eta_{M 2}^{y}$ are the average of the maximum pressure gradient generated by M2 tide in $x$ and $y$ directions $\left(1 \times 10^{-9} \mathrm{~m} \mathrm{~s}^{-2}\right), \eta_{M f}^{X}, \eta_{M f}^{Y}$ represent the deviation from the average of the pressure gradient during spring-neap tides $\left(1 \times 10^{-9} \mathrm{~m} \mathrm{~s}^{-2}\right), \varphi_{\mathrm{SN}}, \varphi_{\mathrm{M} 2}(0 \mathrm{~h}), T_{\mathrm{SN}}(336 \mathrm{~h}=14 \mathrm{~d})$ and $T_{\mathrm{M} 2}$ $(12.4 \mathrm{~h})$ are phases and periods of the spring-neap and M2 tides, respectively (Warrach 1998), $t$ is time (s), I is irradiance $\left(\mathrm{W} \mathrm{m}^{-2}\right.$ ) and $C_{p}$ is the specific heat of seawater (4088 $\mathrm{J} \mathrm{kg}^{-1} \mathrm{~K}^{-1}$; Pollard et al. 1983). The first term on the righthand side of Eqs. (A6) and (A7) represents an approach to the tidal cycle, the second term is the eddy diffusivity, the third term is the Coriolis acceleration $\left(f=1.45 \times 10^{-4} \mathrm{sin}\right.$ $(1 \times \pi / 180,1$ : latitude $)$, and the last term $\left(\varepsilon=1.16 \times 10^{-7}\right.$ $\mathrm{s}^{-1}$ ) represents dissipation parameterization such as Rayleigh friction, Newtonian damping and the pressure gradient generated by currents (DeYoung et al. 1993). Being 1-dimensional, the model cannot model sea-surface slope and pressure gradients. The dissipation parameter $(\varepsilon)$ is necessary to prevent the current from increasing unrealistically.

Since our objective was to capture climatological forcing on a marine ecosystem, the boundary conditions and energy fluxes at the sea-air interface are of particular importance:

$$
\begin{aligned}
& \left.\frac{\partial}{\partial z}\left(K_{q}(z) \frac{\partial}{\partial z}\left(\frac{q^{2}}{2}\right)\right)\right|_{z=0}=\frac{\left(\omega *_{s}\right)^{2}}{2}\left(\frac{B_{1}}{S_{M}}\right)^{\frac{1}{2}} \\
& \left.\frac{\partial}{\partial z}\left(K_{M}(z) \frac{\partial u}{\partial z}\right)\right|_{z=0}=\frac{\tau_{x}}{\rho_{s} \mathrm{~d} z} \\
& \left.\frac{\partial}{\partial z}\left(K_{M}(z) \frac{\partial y}{\partial z}\right)\right|_{z=0}=\frac{\tau_{y}}{\rho_{s} \mathrm{~d} z} \\
& \left.\frac{\partial}{\partial z}\left(K_{z}(z) \frac{\partial T}{\partial z}\right)\right|_{z=0}=\frac{\theta_{H}}{\rho_{s} C_{p} \mathrm{~d} z} \\
& \left.\frac{\partial}{\partial z}\left(K_{z}(z) \frac{\partial S}{\partial z}\right)\right|_{z=0}=\frac{\theta_{S}}{\mathrm{~d} z}
\end{aligned}
$$

where $\omega_{* s}$ is wind-friction velocity, $\tau_{x}$ and $\tau_{y}$ are wind friction in $x$ and $y$ directions, respectively, $\rho_{s}$ is surface water density, $\theta_{H}$ is total heat flux at the sea surface, and $\theta_{s}$ is the salinity flux at the sea surface. Salinity flux includes salinity changes due to evaporation and precipation, ice formation and melting at high latitudes in the NW Atlantic generate seasonality of salinity in coastal current waters. These seasonal changes were also observed in Conception Bay, which shows a regular salinity decrease from May/June to September/October and an increase in winter (DeYoung \& Sanderson 1995). As our 1D model could not capture horizontal advection and freshwater discharge, we added a surface salinity flux, -0.35 $\mathrm{d}^{-1}$ from Calendar Day 122 (May 1) to Day 303 (October 31) and $+0.96 \mathrm{~d}^{-1}$ from Day 1 (January 1) to Day 60 (March 1). The total of this additional salinity flux is thus zero on an annual cycle. These values are empirical, and allowed us to simulate field observations (see section 'Comparison between simulation and observations'). Wind stress $(\tau)$ and friction velocity $\left(\omega_{* s}\right)$ were determined as: 
Appendix 1 (continued)

$$
\begin{gathered}
C_{D}=\left(0.8+0.065 U_{10}\right) \times 10^{-3} \\
\tau_{s}(x, y)=-C_{D} \rho_{a} \sqrt{\left(u_{W}^{2}+V_{W}^{2}\right)} u_{W}, V_{W} \\
\omega_{* S}^{2}=\frac{\tau_{s}}{\rho_{s}}
\end{gathered}
$$

where $C_{D}$ is wind drag coefficient, $U_{10}$ is wind velocity, $\rho_{a}$ is air density $\left(\mathrm{kg} \mathrm{m}^{-3}\right) ; u_{W}$ and $V_{W}$ are wind velocity in $X$ and $y$ direction, respectively. The total heat flux at the sea surface $\left(Q_{H}\right)$ is composed of sensible heat $(\mathrm{SH})$, latent heat $(\mathrm{LH})$, longwave radiation (LW) and shortwave radiation (SW):

$$
Q_{H}=\mathrm{SH}+\mathrm{LH}+\mathrm{LW}+\mathrm{SW}
$$

Sensible heat was calculated as

$$
\begin{aligned}
\mathrm{SH} & =\rho_{a} C_{a} C_{H} U_{10}\left(T_{a}-T_{s}\right) \\
\rho_{a} & =\frac{1}{287\left(T_{a}+273.2\right)}
\end{aligned}
$$

where $C_{a}$ is air-specific heat $\left(1004 \mathrm{~J} \mathrm{~kg}^{-1} \mathrm{~K}^{-1}\right.$; Parkinson \& Washington 1979), $C_{H}$ is the heat-transfer coefficient $(1.75 \times$ $\left.10^{-3} \mathrm{~s}^{-1}\right), T_{a}$ is the air temperature, and $T_{s}$ is the surface water temperature (Archer et al. 1993).

Latent heat was determined as:

$$
\begin{aligned}
& \mathrm{LH}=\rho_{a} C_{E} C_{H} U_{10}\left(q_{a}-q_{s}\right) \\
& q_{a}=\frac{\varepsilon e_{a}}{p-(1-\varepsilon) e_{a}}, \quad q_{s}=\frac{\varepsilon e_{s}}{p-(1-\varepsilon) e_{s}} \\
& e_{a}=611 \times 10^{a(T d-273.2) /(T d-b)}, e_{s}=611 \times 10^{a(T d-273.2) /(T s-b)} \\
& T_{d}=\frac{T_{a}}{1+4.25 \times 10^{-4} T_{a}(-\log H r)}
\end{aligned}
$$

where $C_{E}$ is the latent heat of vaporization $\left(2.5 \times 10^{6} \mathrm{~J} \mathrm{~kg}^{-1}\right)$, $q_{a}$ is specific humidity at $10 \mathrm{~m}$ (or air), $q_{s}$ is specific humidity at the sea surface, $\varepsilon$ is the ratio between the molecular weight of water vapor and that of dry air (0.622), $e_{a}$ is vapor pressure, $e_{s}$ is saturation vapor pressure, $T_{d}$ is dew point, $a=7.5, b=35.86$ and $H r$ is relative humidity (Parkinson \& Washington 1979, Iribarne \& Godson 1981).

Long-wave radiation is calculated as:

$$
\begin{gathered}
\mathrm{LWI}=\alpha T_{a}^{4}\left\{1-0.261 \exp \left[-7.77 \times 10^{-4}\left(273-T_{a}\right)^{2}\right]\right\} \\
\mathrm{LW}=0.97 \mathrm{LWI}(1+0.75 f C)-0.97 \sigma T_{s}^{4}
\end{gathered}
$$

where LWI is the incoming long-wave radiation, LW is net long-wave radiation, $f_{C}$ is fractional cloud cover, $\sigma$ is the Stefan-Boltzman constant $\left(5.67 \times 10^{-8} \mathrm{~J} \mathrm{~m}^{-2} \mathrm{~s}^{-1} \mathrm{~K}^{-1}\right.$; Parkinson \& Washington 1979, Pollard et al. 1983).

Hourly short-wave radiation is formulated as:

$$
\begin{gathered}
\mathrm{SW}(t)=\left(1-\alpha_{g}\right)\left(1-0.7 f_{C} Q(k) /\left(1-0.7 f_{C} \alpha_{g}\right)\right. \\
Q(t)=Q_{S} \sin (H A(t)) / \sum_{\mathrm{SR}} \sin (H A(t)) \\
Q_{S}=\frac{R}{\pi}\left(\frac{d l}{2} \sin (\delta) \sin (l)+\cos (\delta) \cos (l) \sin \left(\frac{d l}{2}\right)\right) \\
d l=0.133 \arccos (-\tan (l) \tan (\delta)) \\
\delta=\frac{\pi}{180}(0.39647-22.9133 \cos (d)+4.02543 \sin (d)- \\
0.3872 \cos (2 d)+0.052 \sin (2 d)) \\
d=2 \pi(i-1) / 364 ; \quad l=\pi \varphi / 180 ; \quad H A(t)=2 \pi t / 24
\end{gathered}
$$

where $\varphi$ is latitude, $i$ is Calendar day, $\delta$ is solar declination, $d l$ is daylength, $Q_{s}$ is total incident radiation, $\alpha_{g}$ is albedo (0.1), $t$ is hour (1 to 24), and HA and $d$ are hour and day expressed in angle units (radians), respectively. Sunrise (SR) and sunset (SD) are determined by the turning points of solar elevation (SE):

$$
\mathrm{SE}(t)=\arcsin (\sin (l) \sin (\delta)-\cos (1) \cos (\delta) \cos (H A(t)))
$$

The turning point of SE from a negative to a positive value is sunrise and that from positive to negative is sunset.

Bottom boundary conditions were formulated as:

$$
\begin{gathered}
\tau_{b}(x, y)=-C_{D b} \rho_{1} \sqrt{\left(u_{b}^{2}+v_{b}^{2}\right)} u_{b}, v_{b} \\
w_{*_{b}}^{2}=\frac{\tau_{b}}{\rho_{s}} \\
\left.\frac{\partial}{\partial z}\left(K_{q}(z) \frac{\partial}{\partial z}\left(\frac{q^{2}}{2}\right)\right)\right|_{z=0}=\frac{\left(\omega *_{b}\right)^{2}}{2}\left(\frac{B_{1}}{S_{M}}\right)^{\frac{1}{2}} \\
\left.\frac{\partial}{\partial z}\left(k_{m}(z) \frac{\partial u}{\partial z}\right)\right|_{z=h}=\frac{\tau_{x}}{\rho d z} \\
\left.\frac{\partial}{\partial z}\left(k_{m}(z) \frac{\partial v}{\partial z}\right)\right|_{z=h}=\frac{\tau_{y}}{\rho d z}
\end{gathered}
$$

where $\tau_{b}$ is bottom stress, $u_{b}, v_{b}$ are bottom currents and $C_{D b}$ is the bottom drag coefficient $\left(3 \times 10^{-3}\right.$; Sharples \& Tett 1994).
Editorial responsibility: Otto Kinne (Editor), Oldendorf/Luhe, Germany
Submitted: January 20, 2003; Accepted: August 5, 2003 Proofs received from author(s): October 27, 2003 